MARIA DĘBOWSKA* - LUBLIN

\title{
KAPITUŁA KATEDRALNA W ŁUCKU W DOKUMENTACH Z PRZELOMU XVIII I XIX WIEKU
}

\section{Wprowadzenie}

Jak dotychczas nie powstała monografia poświęcona dziejom łuckiej kapituły katedralnej. W opublikowanych już pracach znajdujemy jedynie mniej lub bardziej rozbudowane fragmenty dotyczące tej instytucji ${ }^{1}$. Najwięcej miejsca przeznaczył w swoim opracowaniu do jej zaprezentowania L. Królik ${ }^{2}$. Niestety, jego przemyślenia odnoszące się do problematyki związanej ze wspomnianą kapitułą kończą się właściwie na roku 1793, to jest na dacie powstania i złożenia w Rzymie przez bpa Adama Naruszewicza relacji o stanie diecezji łuckiej i brzeskiej.

Miał rację B. Kumor twierdząc ${ }^{3}$, że ani ukaz cara Pawła I z 28 kwietnia (9 maja) 1798 r., ani dokumenty delegata apostolskiego Wawrzyńca Litty z 8-11 sierpnia 1798 r., ani bulla papieża Piusa VI z 15 listopada 1798 r. (Maximis undique pressi) nie wprowadziły żadnych zmian w ustroju łuckiej kapituły katedralnej, co sugerują niektórzy autorzy ${ }^{4}$. Łucka kapituła katedralna, podobnie jak inne takie instytucje na tzw. ziemiach zabranych, zachowała staropolski charakter do momentu konfiskaty majątku nieruchomego kapituły, zarówno tego wspólnego, jak i uposażenia poszczególnych prałatów i kanoników. Ukazem cara Mikołaja I z 25 grudnia 1841 r. (8 stycznia 1842 r.) dobra kapituł katedralnych zostały prze-

* Maria Dębowska - dr hab. historii, profesor w Ośrodku Archiwów Bibliotek i Muzeów Kościelnych KUL.

${ }^{1}$ Na przykład Inna Szostak w pracy Łućko-żytomyrśka diecezija naprykinci XVIII - u perszij potowyni XIX stolit', Biłyj Dunaec' 2005, s. 50-51 jedynie powtórzyła powszechnie znane ogólniki.

${ }^{2}$ L. Królik, Organizacja diecezji łuckiej i brzeskiej od XVI do XVIII wieku, Lublin 1983, s. 196-211 .

${ }^{3}$ B. Kumor, Ustrój i organizacja Kościoła polskiego w okresie niewoli narodowej (1772-1918), Kraków 1980, s. 304.

${ }^{4}$ P. Grabczak, Seminaria duchowne tucko-żytomierskiej diecezji w latach 1798-1842, Biały Dunajec-Ostróg 2006, s. 60-61; B. Modzelewska, Łucka diecezja, w: Encyklopedia katolicka, t. 11, Lublin 2006, kol. 596. 
jęte w administrację skarbu państwa, a członkowie kapituł otrzymywali odtąd dotacje wypłacane przez tenże skarb ${ }^{5}$.

Prawdopodobnie w pierwszym dziesięcioleciu XIX w. członkowie łuckiej kapituły katedralnej sami przygotowali projekt zmian w ustroju i działalności tej instytucji. Jednym $\mathrm{z}$ ich postulatów było zniesienie prałatury związanej z funkcją archidiakona brzeskiego. Biskup łucko-żytomierski Kasper Cieciszowski otrzymał do zaopiniowania projekt reorganizacji kapituły. Uznał, że „,prelatury umniejszać nie można, każda albowiem ma przywiązany obowiązek, jedna tylko archidiakonia brzeska ubywa, jako mająca tytuł obcej teraz diecezyi. Liczbę kanoników zachować możemy" ". Z uwagi na fakt, że prałaturę archidiakona brzeskiego posiadał sufragan łucki, biskup tytularny Chariopolis, Jan Chryzostom Kaczkowski, a ten zmarł 24 lutego 1816 r. w wieku 72 lat w Dubnie jako dziekan kapituły łuckiej ${ }^{7}$, można przyjąć, że reforma kapituły została przeprowadzona w pierwszym dziesięcioleciu XIX wieku ${ }^{8}$. Po śmierci prepozyta, bpa Leona Konstantego Sosnowskiego, który zmarł 11 marca 1802 r. godność prepozyta najprawdopodobniej otrzymał jego koadiutor „,Z przyszłym następstwem” (Dokument $n r$ l) ks. Józef Jan Nepomucen Junosza Piaskowski. Ten jednakże zmarł już w rok później, bo 7 (19) marca 1803 r. Wówczas musiały nastąpić przesunięcia w kapitule. Prawdopodobnie wtedy dziekan kapituły Jan Kanty Bożydar Podhorodeński został prepozytem ${ }^{9}$ ze względu na to, że był najstarszym stażem członkiem kapituły łuckiej: od 1762 - kustosz, 1766 - archidiakon, 1797 - dziekan ${ }^{10}$ („Dawność ta czasu od wejścia jego w wspomniane zgromadzenie, między współczesnemi teraz prałatami i kanonikami uczyniła onego seniorem kapituły" - Dokument $n r$ 1), a godność dziekana kapituły otrzymał bp Jan Chryzostom Kaczkowski (archidiakon brzeski). Przypuszczalnie po tych przesunięciach nie obsadzano już prałatury archidiakona brzeskiego.

Do obecnych czasów nie przetrwało zbyt wiele materiałów archiwalnych, które pozwoliłyby pokazać całościowy obraz łuckiej kapituły katedralnej. To ubóstwo materiałów archiwalnych w odniesieniu do okresu sprzed XIX w. pokazuje już opracowanie L. Królika. Wydaje się, że kolejny okres (XIX-XX w.) w dziejach tej instytucji jest jeszcze mniej udokumentowany. Wobec powyższego, na włączenie do obiegu naukowego przez opublikowanie zasługuje każdy, nieznany jeszcze, dokument wytworzony przez tę instytucję, bądź też do niej się odnoszący.

${ }^{5}$ Kumor, Ustrój i organizacja, s. 305-306.

${ }^{6}$ Archiwum Diecezji Łuckiej [dalej cyt.: ADŁ], Materiały bpa Kaspra Cieciszowskiego, Uwagi do projektu zmian w ustroju kapituły katedralnej w Łucku. Niestety nie odnaleziono samego projektu zmian przygotowanego przez członków kapituły.

${ }^{7}$ S. Tylus, Nowe źródta do biografii biskupów: Jana Chryzostoma Kaczkowskiego (1744-1816) i Jakuba Ignacego Dederki (1750-1829), „Archiwa, Biblioteki i Muzea Kościelne” [dalej cyt.: ABMK], t. 66 (1996) s. 460.

${ }^{8} \mathrm{~W} 1825$ r. prałatury archidiakona brzeskiego w łuckiej kapitule katedralnej już nie było, zob. Kumor, Ustrój i organizacja, s. 305.

${ }^{9}$ W październiku 1802 r. Podhorodeński podpisywał się jeszcze jako dziekan kapituły, a w kwietniu roku następnego występował już jako prepozyt.

${ }^{10}$ Nominacja nastąpiła najprawdopodobniej w końcu 1797 r. W lutym 1797 r. podpisywał się jako archidiakon, a w grudniu tego roku występował już jako dziekan kapituły. 
Szczególną uwagę należałoby zwrócić na raport o łuckiej kapitule katedralnej przygotowany w Łucku przez członków tejże, na życzenie biskupa Kaspra Cieciszowskiego, ordynariusza, zniesionej samowolnie przez Katarzynę II, diecezji kijowskiej i nominata niekanonicznej diecezji pińskiej. Wzmiankowany raport (projekt) został przygotowany w grudniu $1797 \mathrm{r}$. i przesłany (czystopis) w styczniu 1798 r. do Berdyczowa, bo tam, w klasztorze karmelitów bosych bp Cieciszowski miał swoją tymczasową rezydencję ${ }^{11}$. Jest to ostatnia relacja o kapitule katedralnej w Łucku, sporządzona na kilka miesięcy przed powiązaniem diecezji łuckiej i żytomierskiej unią personalną (dekret W. Litty z 8 VIII 1798 r.); pierwszym rządcą połączonych diecezji został bp Cieciszowski. Dokument ten jest ważny nie tylko $\mathrm{z}$ tego powodu, że zawiera życiorysy członków kapituły, wykaz ich obowiązków, uposażenie wspólne kapituły i poszczególnych prałatów i kanoników, ale - co jest również interesujące - są tam także zaprezentowane wszystkie osoby (większość z imienia i nazwiska) posługujące w kościele katedralnym i z nim związane (np. fioleci, seminarzyści). Krótka notatka została poświęcona samej parafii katedralnej. Poniżej (Dokument $n r$ l) publikowany jest projekt (brudnopis) tego raportu z uwzględnieniem wszystkich poprawek i skreśleń.

Dwa pozostałe dokumenty, zamieszczone poniżej, nie są datowane. Wiemy jednak, że zostały przygotowane krótko po powołaniu do życia diecezji łuckożytomierskiej. Można z dużą dozą pewności przyjąć, że pierwszy z nich (Dokument $n r 2$ ) powstał w $1800 \mathrm{r}$. Drugi zaś (Dokument $n r$ 3) został sporządzony po 1799 r., być może także w 1800 r. lub wkrótce potem.

Te trzy dokumenty pokazują stan kapituły na przestrzeni krótkiego okresu czasu - trzech lub czterech lat. Nie mogły więc nastąpić jakieś zasadnicze zmiany w jej ustroju. Ale to jest także ważna konstatacja, kiedy weźmie się pod uwagę twierdzenie niektórych autorów, że W. Litta dokonał jakichś zmian w tej instytucji. Drugi dokument pokazuje obsadę kapituły katedralnej w Łucku w pierwszych latach po utworzeniu diecezji łucko-żytomierskiej. Znajdujemy w nim potwierdzenie, że ustrój tej kapituły nie zmienił się w pierwszych latach po trzecim rozbiorze Polski.

Zdecydowano się opublikować te trzy dokumenty, gdyż każdy z nich wnosi jakieś nowe treści do dziejów tej instytucji.

Gdzie były przechowywane archiwalia kapituły katedralnej w Łucku, a więc także omówione wyżej dokumenty? Odpowiedź brzmi, że in archivo capituli w Łucku. Prawdopodobnie zawsze pozostawały na jednym miejscu, w pomieszczeniach łuckiej kapituły katedralnej w Łucku. W diecezji łucko-żytomierskiej istniały dwie kapituły przy kościołach katedralnych w Łucku i Żytomierzu. Nowy rządca tych diecezji odbywał ingres najpierw do katedry luckiej. Wyjątkiem był bp Ignacy Dub-Dubowski, który - ze względu na warunki wojenne - odbył ingres najpierw do katedry w Żytomierzu, a dopiero w 1919 r. - do katedry w Łucku.

${ }^{11}$ Będąc biskupem nominatem pińskim K. Cieciszowski mieszkał w klasztorze karmelitów bosych w Berdyczowie - „[...] do Berdyczowa, do klasztoru WW. OO. Karmelitów Bosych, w którym tymczasową rezydencyją naszą założyliśmy", ADŁ, Parafia w Bereznem, Liber processuum, k. 20v. Cytat pochodzi z zarządzenia bpa Cieciszowskiego (z 24 XII 1795 r.), skierowanego do przełożonych zakonnych i proboszczów na terenie niekanonicznej diecezji pińskiej. 
W pierwszych kilkudziesięciu latach funkcjonowania diecezji łucko-żytomierskiej w kapitułach łuckiej i żytomierskiej zasiadali odrębni tytulariusze. Natomiast po przejęciu majątków kapitulnych w latach czterdziestych XIX w. i wypłacaniu członkom kapituł dotacji ze skarbu państwa, sytuacja się zmieniła. Wymierających członków kapituł nie zastępowano nowymi osobami. Pod koniec XIX w. istniały wprawdzie dwie kapituły, ale z tymi samymi tytulariuszami ${ }^{12}$. Jedyna różnica polegała na tym, że w Żytomierzu pierwszym prałatem był dziekan (w huckiej kapitule zajmował drugie miejsce), a w Łucku prepozyt, który z kolei w kapitule żytomierskiej zajmował drugie miejsce.

Ze względu na to, że siedziba biskupa w latach czterdziestych XIX w. została przeniesiona do Żytomierza, więc, gdy pozostał już tylko jeden „komplet” tytulariuszy, mieszkali oni na stałe w Żytomierzu. Praktycznie więc akta wytworzone przez kapitułę w drugiej połowie XIX i dwóch pierwszych dziesięcioleciach XX w. były deponowane w siedzibie kapituły w Żytomierzu. Akta wytworzone przez kapitułę łucką do czasu kiedy byli jeszcze odrębni prałaci i kanonicy w obydwóch kapitułach, pozostały w Łucku. Prawdopodobnie nie zostały przewiezione do Żytomierza, bo gdyby tak się stało, obecne wydanie wzmiankowanych dokumentów, być może, nie doszłoby do skutku.

Ubóstwo archiwaliów kapituły łuckiej, które przetrwały do dzisiaj świadczy, że na skutek klęsk żywiołowych (pożary miasta), pierwszej wojny światowej lub zawirowań politycznych uległy one $\mathrm{w}$ większości zniszczeniu lub rozproszeniu. Aktami, które dotrwały do odzyskania przez Polskę niepodległości w 1918 r. zaopiekowali się prałaci, którzy po opuszczenia Żytomierza zamieszkali w Łucku. Najbardziej zainteresowanym pamiątkami przeszłości łuckiej kapituły był z pewnością ks. Florentyn Czyżewski, przewodniczący sekcji statystyczno-archiwalnej w Kurii Diecezjalnej w Łucku. Po drugiej wojnie światowej archiwalia te zostały przewiezione do Polski razem ze szczątkami akt kurii. Obecnie znajdują się w depozycie w Ośrodku Archiwów, Bibliotek i Muzeów Kościelnych Katolickiego Uniwersytetu Lubelskiego Jana Pawła II. Dokumenty obecnie publikowane należą do szczątkowego zespołu archiwalnego pod nazwą Kapituła Katedralna w Łucku' ${ }^{13}$.

Zachowano w zasadzie układ dokumentów nadany im w kancelarii kapitulnej. Odstapiono od tego w przypadku dokumentu publikowanego jako drugi w kolejności (Dokument $n r$ 2). Temu w kancelarii nadano formę tabeli. Tutaj, dla uzyskania większej przejrzystości zamieszczonych tam informacji zrezygnowano z ujęcia tabelarycznego. Przygotowując dokumenty do druku uwspółcześniono ortografię, wytłuszczono niektóre informacje oraz wprowadzono podział na segmenty tam, gdzie tekst w oryginale jest spisany w sposób ciągły, a to wszystko uczyniono dla uzyskania większej przejrzystości tekstu. Konieczne uzupełnienia zostały podane w nawiasach kwadratowych.

${ }^{12}$ X.K.N. [Karol Niedziałkowski], Euckie biskupstwo obrzadku łacińskiego, w: Encyklopedia kościelna, wyd. M. Nowodworski, t. 12, Warszawa 1879, s. 619.

${ }^{13}$ Dwa pierwsze dokumenty mają formę składek (Dokument $n r 1$ jest zszyty), a trzeci został sporządzony w postaci podwójnej karty. Wymiary i objętość: dokument nr $1-34,5$ x 20,7 cm, kart 14; dokument nr $2-35$ x 21,5 cm, kart 6; dokument nr $3-35$ x 21,7 cm, kart 2. 
$* * * * *$

\section{Dokument $n r 1$}

Do jaśnie wielmożnego imci księdza Kaspra Kazimierza Kolumny Cieciszowskiego, biskupa kościołów rzymsko-katolickich w guberniach mińskiej i wołyńskiej, nominowanego pińskiego, kawalera orderów Świętego Aleksandra Newskiego, Orła Białego i Świętego Stanisława

\section{Od kościoła katedralnego oraz parafialnego łuckiego Rapport}

Obwieszczenie pasterskie o podaniu wiadomości stanu duchowieństwa z ukazem Departamentu Collegii Justiciae ${ }^{14}$ kapituła łucka, zgromadziwszy się dnia siódmego grudnia roku 1797, odebrała, które dopełniając rapportuje.

Kościół katedralny a oraz parafialny w mieście Łucku, w guberni wołyńskiej, powiecie łuckim będący, przy którym jest:

\section{Kapituła}

składająca się z duchowieństwa świeckiego - prałatów i kanoników mających swoje dochody, tudzież kanoników bez żadnego dochodu, nad liczbę pierwszych dla zastępstwa i pomocy w ich obowiązkach, do zgromadzenia kapituły przypuszczonych. Jest oraz przy tymże kościele fundowane świeckie także duchowieństwo niższe: wikariusze, mansjonarze, angeliści i seminarium.

Dochody kapituły są dwojakie: jedne szczególne, należące do osób, nazywające się praestimonia, drugie wspólne, ad massam capitularem należące. Szczególne dochody mają następujący:

\section{Pralaci}

1. Suffragan łucki. Jaśnie wielmożny imć ks. Jan Chryzostom Kaczkowski ${ }^{15}$, biskup kariopolitański, archidiakon brzeski, proboszcz dubieński, orderu Świętego Stanisława kawaler, zawsze w kraju mieszkający.

${ }^{14}$ Od 1717 r. istniało w Petersburgu Justickolegium dla spraw Kościoła protestanckiego Inflant, Estonii i Finlandii. Ukazem z 26 II 1797 r. car Paweł I utworzył przy tejże instytucji Departament do Spraw Kościoła Katolickiego. Po roku (ukazem z 26 I i 15 II 1798 r.) car odłączył tenże Departament od Justickolegium i na jego czele postawił metropolitę Stanisława Siestrzeńcewicza (B. Kumor, Historia Kościoła, cz. 6, Lublin 1985, s. 232-233). Nakaz sporządzenia raportu został więc wydany wówczas, gdy Departament do Spraw Kościoła Katolickiego był przyłączony do Justickolegium.

${ }^{15}$ Jan Chryzostom Kaczkowski (1744-1816), syn Aleksandra i Doroty z Kobielskich urodził się w Lisowczycach, w parafii Kodrąb (archidiecezja gnieźnieńska, obecnie częstochowska). Został ochrzczony 26 I 1744 r. w kościele parafialnym w Kodrąbiu. Święcenia kapłańskie przyjął 26 IV 1767 r. w kościele kolegiackim w Janowie Podlaskim. Doktorat obojga praw otrzymał w Rzymie 22 I 1744 r. W 1778 r. został kanonikiem łuckim. Prekonizowany biskupem tytularnym Chariopolis i sufraganem łuckim 25 VI 1781 r. Zmarł 24 II 1816 r. w Dubnie w wieku 72 lat jako proboszcz dubieński i mielnicki oraz dziekan łuckiej kapituły katedralnej, ADŁ, Księga zmarłych kapłanów 
Fundusz tej suffraganii jest na dochodzie ze wsiów Kołodeżno i Budyszcze zwanych, w guberni wołyńskiej, w powiecie kowelskim leżących, który dochód zaprzysiężony, rocznie wynosi złotych polskich 3200 groszy 13. We wsi Kołodeżny znajduje się dusz 94, we wsi zaś Budyszczach dusz 32.

2. Proboszcz ${ }^{16}$ katedralny lucki i brzeski. Jaśnie wielmożny imć ks. Leo Konstantyn Sosnowski ${ }^{17}$, biskup aretuzjański.

Fundusz tego probostwa jest na dochodach Szebryn zwanych, w guberni litewskiej a powiecie brzeskim litewskim będących, z których dochód zaprzysiężony rocznie wynosi złotych polskich 7630 groszy 4; w których dobrach znajduje się dusz 846. Tenże jaśnie wielmożny imć ksiądz proboszcz, dla osłabionego wiekiem zdrowia, mieszka w rzeczonych dobrach Szebryn ${ }^{18}$, mający koadiutora rzeczonego probostwa z przyszłym następstwem, jaśnie wielmożnego imci księdza Józefa Jana Nepomucena Junoszę Piaskowskiego $^{19}$ obojga prawa doktora, [ ${ }^{a}$ ] oraz proboszcza rówieńskiego, orderu Świętego Stanisława kawalera. Który koadiutor z dóbr proboszczowskich Szebrynia mający roczny, tymczaso-

${ }^{a}$ Wykreślono w oryginale: katedralnego krakowskiego kanonika, dziekana kollegiaty ołyckiej, proboszcza infułata klimontowskiego.

łuckich, s. 63; Archivum Secretum Vaticanum, Proc. Conist., vol. 181, k. 93v-94; Tylus, Nowe źródła do biografii biskupów, s. 460.

${ }^{16}$ Prałatura prepozyta została utworzona przez bpa Stanisława Gomolińskiego 22 I 1602 r. Pierwszym prepozytem był ks. Franciszek Zajerski, Królik, Organizacja diecezji łuckiej i brzeskiej, s. 200-201.

${ }^{17}$ Leon Konstanty Sosnowski (1722-1802), syn Marcina i Teofili z Kruszyńskich, urodzony w Sosnowicy, ochrzczony 3 V 1722 r. w kościele parafialnym w Janowie Podlaskim. Był bratem Józefa Sylwestra Sosnowskiego, hetmana polnego litewskiego, ojca Ludwiki, ukochanej Tadeusza Kościuszki. Wstąpił do zakonu paulinów (profesja 24 X 1751 r.). Prekonizowany biskupem tytularnym Arethusa i sufraganem inflanckim 16 II 1767 r., konsekrowany w kościele misjonarzy św. Wincentego a Paulo w Warszawie 30 III 1767 r. Po rezygnacji z sufraganii 16 VI 1780 r., otrzymał godność prałata-prepozyta kapituły łuckiej. Zmarł 5 III 1802 r. w wieku 80 lat w Ratnie (pochowany tamże 11 III), zob. ADŁ, Księga zmarłych, s. 82; K.R. Prokop, Wiadomości do biografii biskupów oraz opatów i ksień z ziem Rzeczypospolitej Obojga Narodów i osiemnastowiecznej prasy warszawskiej doby saskiej i stanistawowskiej (1729-1795), ABMK, t. 86 (2006) s. 320; tenże, Wypisy źródtowe do biografii polskich biskupów i opatów z czasów Rzeczypospolitej Obojga Narodów oraz niewoli narodowej doby zaborów (XVI-XIX w.), ABMK, t. 95 (2011) s. 284-285; S. Tylus, W sprawie datacji śmierci niektórych biskupów kresowych, ABMK, t. 70 (1998) s. 359.

${ }^{18}$ Bp Leon Konstanty Sosnowski ufundował w Szebrynie w 1793 r. cerkiew pod wezwaniem Przeczystej Bogarodzicy.

${ }^{19}$ Ks. Józef Jan Nepomucen Piaskowski (1743/1744-1803) h. Junosza, doktor obojga praw. Początkowo uczył się w klasztorach łuckich i lubelskich. W 21 roku życia rozpoczął przygotowanie do kapłaństwa w seminarium Św. Krzyża w Warszawie. Po złożeniu egzaminów w Akademii Krakowskiej otrzymał stopień doktora obojga praw. Był kanclerzem krakowskiej kapituły katedralnej (kanonia prebendy Staniątecka, instalacja 5 II 1774 r. - 1783), prepozytem koadiutorem kapituły katedralnej w Łucku, dziekanem kapituły kolegiackiej w Ołyce, prepozytem klimontowskiej kapituły kolegiackiej. W ostatnich latach życia był proboszczem parafii rówieńskiej, gdzie zwykle mieszkał. Z ramienia kapituły krakowskiej był deputatem do Trybunału Koronnego lubelskiego i delegatem od tegoż Trybunału do króla. Pełnił również funkcję komisarza cywilno-wojskowego. W kapitule łuckiej sprawował przez pewien czas obowiązki prokuratora. Został odznaczony orderem Świętego Stanisława. Zmarł 7 (19) marca 1803 r. w Międzyrzecu Koreckim, został pochowany w Ołyce, ADŁ, „Historia kościołów ołyckich. Ich fundacje i fundatorzy. Zeszyt II”, k. 32-33, Księga 
wie do życia swego koadiuta umówiony, dochód złotych polskich 2500 sobie wydzielony. Obowiązki proboszczowskie w katedrze i kapitule łuckiej, zawsze w kraju mieszkający, zastępuje.

3. Dziekan ${ }^{20}$. Jaśnie wielmożny imć ks. Jan Kanty Bożydar Podhorodeński ${ }^{21}$, obojga prawa doktor, officjał łucki, kawaler orderu Świętego Stanisława, syn jaśnie wielmożnego Ludwika Bożydar Podhorodeńskiego, kasztelana czerniechowskiego, orderów Orła Białego i Świętego Stanisława kawalera ${ }^{22}$. Zawsze w kraju mieszkający. Początków nauk nabywał w Akademii Zamojskiej, w której był potym publicznym professorem. Dalsze do duchowieństwa ściągające się nauki brał w Rzymie, gdzie i na kapłaństwo został poświęcony. Doktora praw obojga, duchownego i cywilnego, w rzeczonej Akademii Zamojskiej otrzymał stopień. W kapitule katedralnej łuckiej przed lat 38 umieszczony, wprzód prałatem kustoszem będąc, postapił w roku 1766 na archidiakona dostojność, teraz dziekańską posiada prelaturę ${ }^{23}$. Dawność ta czasu od wejścia jego w wspomniane zgromadzenie, między współczesnemi teraz prałatami i kanonikami uczyniła onego seniorem kapituły. Odbywał prace parafialne, wprzód zbarazkiego, potym ostrowieckiego, następnie poryckiego, na koniec zwiahelskiego plebana nosząc urząd. Konsystorza biskupiego tuckiego wprzód przez lat pięć będąc sędzią surrogatem, potym w diecezyi łuckiej namiestnika biskupiego przez lat 23 sprawował rządy. Zasługując się publiczności krajowej, sędziego deputata po dwa razy w trybunałach najwyższych, tudzież kilkakrotnie reskryptami Tronu Polskiego naznaczony, sędziego kommissarza w sprawach cywilnych, jako też kommissarza cywilno-wojskowego odbywał funkcyje; niemniej delegata na sejmy walne narodowe podług praw kapitułom służących przy biskupach łuckich oraz na kongress generalny duchowieństwa polskiego, jako też różnych ważnych diecezyi i całego duchowieństwa interessów sobie od biskupów i kapituły katedralnej łuckiej powierzanych dopełniał obowiązki. Na koniec, podczas szczęśliwej koronacyi najjaśniejszego i najpotężniejszego Pawła Pierwszego, imperatora i samowładcy całej Rossyi, pana naszego najmiłościwszego, bytnością w stolicy państw jego zaszczyconym zosta2 ${ }^{24}$.

Ma fundusz na dobrach Lubaszki zwanych, w guberni litewskiej, a powiecie brzeskim litewskim leżących, z których dochód roczny wynosi złotych polskich 3875. Dusz w tych dobrach znajduje się 187 .

zmarłych, s. 91; J. Szczepaniak, Spis prałatów i kanoników kapituły katedralnej oraz kapituł kolegiackich diecezji krakowskiej (XVIII w.), Kraków 2008, s. 15.

${ }^{20}$ Ta prałatura istniała od początku kapituły. Dziekan stracił pierwszeństwo w kapitule na rzecz prepozyta w 1602 r., Królik, Organizacja diecezji łuckiej i brzeskiej, s. 198.

${ }^{21}$ Jan Kanty Bożydar Podhorodeński (1741-1832) urodził się w miejscowości Wohyn, ochrzczony został 16 X 1741 r. w kościele parafialnym we Włodzimierzu Wołyńskim. Prekonizowany biskupem tytularnym Polemonium i sufraganem żytomierskim 20 VIII 1804 r. Po śmierci bpa J.Ch. Kaczkowskiego przeniesiony na sufraganię łucką. Zmarł 4 XII 1832 r. w Dereczynie, a pochowany został w Łucku, K.R. Prokop, Diario Ordinario oraz Notizie rzymskich drukarzy Cracas (Chracas) jako źródto informacji do dziejów hierarchii Kościoła katolickiego w Rzeczypospolitej Obojga Narodów u schytku epoki staropolskiej, ABMK, t. 90 (2008) s. 137; S. Tylus, Podhorodeński Jan Kanty, w: Encyklopedia katolicka, t. 15, Lublin 2011, kol. 938.

${ }^{22}$ Jan Kanty był synem Ludwika i Franciszki z Cieszkowskich (kasztelanki czernihowskiej), K.R. Prokop, Wypisy źródłowe do biografii polskich biskupów i opatów z czasów Rzeczypospolitej Obojga Narodów oraz niewoli narodowej doby zaborów, ABMK, t. 84 (2005) s. 264-265.

${ }^{23}$ Nie jest więc prawdą twierdzenie S. Tylusa, że Podhorodeński został w 1791 r. prepozytem kapituły łuckiej, zob. Tylus, Podhorodeński Jan Kanty, kol. 938.

${ }^{24} \mathrm{~W}$ kwietniu $1797 \mathrm{r}$. 
4. Archidiakon lucki ${ }^{25}$. Wielmożny imć ks. Józef Umińskii ${ }^{26}$, proboszcz ostrogski, zawsze w kraju mieszkający.

Ma fundusz archidiakonii na połowie wsi Niemieckie zwanej, w guberni wołyńskiej, w powiecie łuckim leżącej, zaprzysiężonego rocznego dochodu czyniącej złotych polskich 866 groszy 15, w której znajduje się dusz 39. Do tegoż funduszu należy dziesięcina $\mathrm{z}$ dóbr Połonna i Korszów zwanych, $\mathrm{w}$ tymże powiecie łuckim leżących, na pieniężną z dawna zamieniona. $Z$ której, wytrąciwszy na szpital lucki pod tytułem Świętego Ducha złotych 28 , zostaje się za dziesięcinę złotych 572 . Z placów także i gruntów różnych w mieście Łucku będących, wraz i z karczmy w Łucku szynk przywilejami królów polskich pozwolony mający do tegoż funduszu podług zaprzysiężenia należących, czynić powinien dochód złotych polskich 1395 , który przez ubóstwo mieszkańców i upadający z karczmy dochód ledwo może czynić złotych 635, jako też za dziesięcinę ze wsi Krasne do starostwa łuckiego należącej corocznie złotych 40; długo już są zawiedzione. Zatym ogólnego dochodu archidiakonia realnie może odbierać złotych 2073 groszy 15. Zawiedzionego zaś, wraz z dziesięciną z Krasnego, dochód wynosi złotych 800 .

5. Kustosz ${ }^{27}$. Jaśnie wielmożny imć ks. Jędrzej Myszka Chołoniewski ${ }^{28}$, obojga prawa doktor, orderu Świętego Stanisława kawaler, zawsze w kraju mieszkający.

Ma fundusz na pensyi złotych polskich $300 \mathrm{z}$ dóbr Sadowa zwanych, w guberni wołyńskiej, w powiecie włodzimierskim będących, do funduszu księży wikariuszów katedralnego łuckiego kościoła należących, sobie corocznie wypłacanej.

6. Archidiakon brzeski ${ }^{29}$. Tę prelaturę posiada jaśnie wielmożny imć ks. Kaczkowski, suffragan łucki, wyżej wyrażony.

Do funduszu rzeczonej archidiakonii należy folwark, grunta i dziesięcina wytyczna w mieście Janowie, przedtym do biskupów łuckich rzymsko-katolickich należącym, które teraz pod panowaniem austriackim zostaje.

${ }^{25}$ Tę prałaturę erygował w 1541 r. bp Jerzy Chwalczewski, Królik, Organizacja diecezji łuckiej i brzeskiej, s. 198.

${ }^{26}$ Józef Umiński zmarł 23 I 1805 r. w Ostrogu w wieku 66 lat, zob. ADŁ, Księga zmarłych, s. 27

${ }^{27}$ Tę prałaturę erygował w 1544 r. bp Jerzy Chwalczewski, Królik, Organizacja diecezji łuckiej i brzeskiej, s. 198.

${ }^{28}$ Andrzej Chołoniewski drugi syn Adama (kasztelana buskiego) i Salomei z Kątskich został ochrzczony 9 VII 1744 r. w kościele parafialnym w Tartakowie. Święcenia kapłańskie otrzymał w 1767 r. Studiował w Rzymie. Posiadał godność kanonika lwowskiego. 20 VIII 1804 r. prekonizowany biskupem tytularnym Arathia i sufraganem kamienieckim, zmarł w styczniu 1806 r., ADŁ, Parafia w Bereznem, Liber processum, k. 79v; K.R. Prokop, Wypisy źródtowe do biografii polskich biskupów i opatów z czasów Rzeczypospolitej Obojga Narodów oraz niewoli narodowej dobry zaborów (XVI-XIX w.), ABMK, t. 84 (2005) s. 245-246; Rodzina. Herbarz szlachty polskiej, oprac. S. Uruski, t. 2, Warszawa 1905, s. 232-233.

${ }^{29}$ Prałaturę archidiakona brzeskiego ufundował w 1717 r. ks. Eliasz Hulewicz, proboszcz rówieński. Formalnie erygował ją bp Stefan Rupniewski w 1721 r. Pierwszym archidiakonem brzeskim był jej fundator, Królik, Organizacja diecezji łuckiej i brzeskiej, s. 202. Ostatnim, który tę prałaturę posiadał był bp Jan Chryzostom Kaczkowski. 
7. Kanclerz ${ }^{30}$. Wielmożny imć ks. Michał Skirniewski ${ }^{31}$, audytor kuryi jaśnie wielmożnego imci księdza biskupa pińskiego, proboszcz klewański, zawsze w kraju mieszkający.

Ma fundusz na dochodzie celnym w Torczynie, dobrach przedtym do biskupa łuckiego rzymsko-katolickiego należących ${ }^{32}$, w guberni wołyńskiej, w powiecie łuckim leżących, z których dóbr dochodu naznaczona mu jest pensyja roczna złotych polskich 200.

8. Kantor ${ }^{33}$. Wielmożny imć ks. Mikołaj Grott Faliszewski ${ }^{34}$, obojga prawa doktor [ $\left.{ }^{b}\right]$, proboszcz ratniański, w kraju zawsze mieszkający.

Miał dożywotnią administracyją funduszu kanoniczego połowy wsi Bokowy, w guberni wołyńskiej, w powiecie łuckim będącejc.

9. Scholastyk ${ }^{35}$. Wielmożny imć ks. Ignacy Mioduszewski ${ }^{36}$, pleban mielnicki, zawsze w kraju mieszkający.

Ma fundusz od summy na kahale Żydów w Międzyrzecu, w guberni wołyńskiej, w powiecie nowogródwołyńskim ${ }^{37}$ lokowanej, rocznego dochodu czyniący złotych polskich 175 , który prowent zalega. Do funduszu jego należy także dziesięcina wytyczna z folwarku dóbr Chotiaczew ${ }^{38}$ zwanych, od Chwalczewskiego, biskupa łuckiego roku 1545 nabytych, w guberni wołyńskiej, w powiecie włodzimierskim leżących, przedtym

\footnotetext{
${ }^{\mathrm{b}}$ Wykreślono w oryginale: kanonik katedralny chełmski. ${ }^{\mathrm{C}}$ Wykreślono w oryginale: który fundusz zaprzysiężonego dochodu mający złotych polskich 1495 , jeszcze przed rewizyją dusz, najwyższego rządu ukazem oddany jest w possesyją jaśnie wielmożnego hrabiego Esterhazego.

${ }^{30}$ Prałatura kanclerza została erygowana w 1703 r. przez bpa Aleksandra Wyhowskiego, Królik, Organizacja diecezji łuckiej i brzeskiej, s. 202.

${ }^{31}$ Ks. Michał Skirniewski urodził się w 1760 r. w rodzinie „ruskiej szlachty”. Do 1777 r. uczył się w szkołach jezuickich i pijarskich. W latach 1777-1789 był członkiem zakonu pijarów. Po opuszczeniu zakonu był kapelanem katolików w wojsku rosyjskim, należał do diecezji kijowskiej (był kanonikiem kijowskim), potem łucko-żytomierskiej (prałat łuckiej kapituły katedralnej, asesor konsystorza generalnego w Łucku). Od 1806 r. był członkiem ołyckiej kapituły kolegiackiej i regensem tamtejszego seminarium (1806-1818). W seminarium ołyckim wykładał teologię dogmatyczną i historię Kościoła, Grabczak, Seminaria duchowne, s. 340. Od 1797 r. do śmierci był proboszczem klewańskim, także dziekanem rówieńskim. Zmarł 19 IV 1831 r. w wieku 71 lat w Klewaniu, zob. ADŁ, Księga zmarłych, s. 126. To on podsunął ociemniałemu abpowi K. Cieciszowskiemu do podpisania dokument potępiający powstanie listopadowe, zob. R. Nir, Cieciszowski Kasper, w: Encyklopedia katolicka, t. 3, Lublin 1979, kol. 464.

${ }^{32}$ Po trzecim rozbiorze Polski, kiedy biskup łucki pozostał poza granicami imperium, władze carskie zarządziły przejęcie klucza torczyńskiego. W 1802 r. bp K. Cieciszowski czynił w Petersburgu starania, by ten majątek odzyskać, zob. ADŁ, Materiały bpa A.P. Szelążka, Polska Rada Rozrachunkowa w Petersburgu (Poszukiwania archiwalne i biblioteczne - Aneks 17c: Ministerstwo Rolnictwa).

${ }^{33}$ Kantorię, ufundowaną przez ks. Ludwika Gnatowskiego, erygował 22 IX 1680 r. bp Stanisław Dąbski, Królik, Organizacja diecezji łuckiej i brzeskiej, s. 201.

${ }^{34}$ Ks. Mikołaj Antoni Grott-Faliszewski, proboszcz ratneński (1773-1809), zmarł 1 XII 1809 r. w wieku 81 lat w Ratnie, zob. ADŁ, Księga zmarłych, s. 384.

${ }^{35}$ Scholasterię erygował bp Bernard Maciejowski w 1591 r., Królik, Organizacja diecezji łuckiej i brzeskiej, s. 200.

${ }^{36}$ Ks. Ignacy Mioduszewski zmarł 17 IX 1807 r. w Łucku w wieku 77 lat, zob. ADŁ, Księga zmarłych, s. 299.

${ }^{37}$ Nowogród Wołyński czyli Zwiahel.

${ }^{38}$ Lub Chotiaczów.
} 
w posiadaniu wprzód łuckiego, potym chełmskiego biskupów rzymsko-katolickich będących, teraz $\mathrm{w}$ possessyi jaśnie wielmożnego Choiseul ${ }^{39}$ zostających. Która dziesięcina, podług zaprzysiężenia, jest oszacowana corocznie złotych polskich 800 . Tej jednak dziesięciny, od lat dwóch [w] possessyi jaśnie wielmożnego Choiseul zatrzymanej, wielmożny imć ksiądz scholastyk nie odbiera.

\section{Kanonicy}

\section{z ich funduszami są następujący:}

1. Kanonik. Wielmożny imć ks. Stanisław Stecki ${ }^{40}$, pleban chabeński, zawsze mieszkający w kraju. Postąpił po imci księdzu Janie Faliszewskim, nie mieszkającym w kraju, na kanonię mającą fundusz na wsi Wiktorzanach, z gruntów Urwichwosty zwanym, w guberni wołyńskiej, w powiecie łuckim leżących, z których dochód roczny zaprzysiężony wynosił złotych polskich 1570 groszy 17. Ta wieś, z gruntem rzeczonym, przed rewizyją dusz, na skarb jest zajęta, a potym jaśnie wielmożnemu generałowi hrabiemu Esterhazemu oddana, przez co fundusz kościelny upada; mający dusz 39.

2. Kanonik. Jaśnie oświecony Janusz książę Jabłonowski ${ }^{41}$, proboszcz kowelski, zawsze w kraju mieszkający.

Ma fundusz na połowie wsi Bokowa, wyżej opisanej, w administracyi wielmożnego imci księdza Faliszewskiego, kantora trzymany, z funduszem kantorskiej prelatury od summy złotych polskich 3000, na dobrach Kniehyninie, w guberni wołyńskiej, w powiecie dubieńskim, z dawna zawiedzionym.

3. Kanonik. Wielmożny imć ks. Marcin Olszewski ${ }^{42}$, pleban skorecki, zawsze w kraju mieszkający.

Fundusz ma na drugiej połowie wsi wyż wspomnianej Bokowy, w której połowie wsi jest dusz 66. Intraty rocznej złotych polskich 1890. Z gruntów zaś, w mieście Łucku będących, ma intraty złotych polskich 26. Cały dochód wynosi złotych polskich 1916.

4. Kanonik ${ }^{43}$. Wielmożny imć ks. Tobiasz, syn Jana, Glinka ${ }^{44}$. W zakonie jezuickim lat 23 przepędziwszy, brał w nim nauki do duchowieństwa potrzebne i na różnych funkcyjach pracował. Po zgaszonym zakonie przy kościele katedralnym łuckim, aż dotąd ciągle w kraju mieszkając, kaznodziejski przez lat 23 sprawował urząd.

${ }^{39} \mathrm{Z}$ rodziny de Choiseul-Gouffier.

${ }^{40}$ Urodził się w $1738 \mathrm{r}$.

${ }^{41}$ Książę Jan Jabłonowski urodził się 6 XII 1754 r., był także kanonikiem kapituły kolegiackiej w Warszawie. Zmarł w Buceniu i tam został pochowany 14 IX 1814 r., S. Tylus, Duchowieństwo Lubomla, Oleksińca, Torczyna i Turzyska. Spis na podstawie materiatów archiwalnych (XVII w. 1826), ABMK, t. 75 (2001) s. 412; tenże, XVIII-wieczne duchowieństwo na kartach metryk parafii Kowel, ABMK, t. 73 (2000) s. 423.

${ }^{42}$ Ks. Marcin Olszewski urodził się w 1736 r. Pracował także na stanowisku sędziego surogata konsystorza łuckiego. Zmarł 3 IX 1804 r. w Łucku, pochowany w kościele bernardyńskim, zob. ADŁ, Księga zmarłych, s. 283.

${ }^{43}$ Kanonię torczyńską ufundował w 1541 r. bp Jerzy Chwalczewski, Królik, Organizacja diecezji tuckiej i brzeskiej, s. 198.

${ }^{44}$ Lukasz Tobiasz Glinka, syn Jana i Aleksandry, urodził się 11 X 1734 r. w Dublanach. Do zakonu jezuitów wstąpił w Krakowie 31 VII 1750 r. Pracował jako misjonarz w Niżborgu i Kopyczyńcach (1763-1765) oraz Turce (1766-1767), prefekt bursy muzyków we Lwowie (1769-1770). Zmarł 4 VII 1798 r. w Łucku, pochowany w kościele bernardyńskim, zob. ADŁ, Księga zmarłych, s. 213; Encyklopedia wiedzy o jezuitach na ziemiach Polski i Litwy 1564-1995, oprac. L. Grzebień, Kraków 1996, s. 181. 
Kanonik ten ma fundusz w mieście Torczynie, w guberni wołyńskiej, w powiecie łuckim leżącym, trzy włóki pola z sianożęciami i placem dla ośmiu poddanych pieszych, ogrodowych zabudowanym, skąd ma dochodu rocznego złotych polskich 285 i groszy 25. Dusz zaś liczba na tymże gruncie znajdujących się 34, wolnych 8. Dla którego dochodu szczupłości, urząd i obowiązki angelisty przy tymże kościele sprawuje.

5. Kanonik penitencjarz ${ }^{45}$. Wielmożny imć ks. Marcin, syn Marcina, Bossakowski ${ }^{46}$. Po odbytych w seminarium katedralnym łuckim naukach do stanu duchownego potrzebnych, w roku 1782 poświęcony na kapłaństwo, otrzymał najprzód wikariat katedralny łucki i zaraz uczyniony był egzaminatorem diecezjalnym oraz do prac nauczania ludu w kościołach był używany. Potym w seminarium wyż rzeczonym został profesorem retoryki duchownej. Dalej viceregensa w seminarium, jako też profesora, wprzód teologii moralnej, później zaś dogmatycznej włożone na siebie sprawując obowiązki, kanonią honoralną łucką zaszczycony, z wikariatu katedralnego na obowiązki angelisty przy tymże kościele został przeniesionym. Ksiąg cenzorem oraz do układania corocznych directoriów officii Divini był wyznaczony. Przy których pracach różne kommissyje w diecezyi z rozkazu zwierzchności duchownej uskuteczniał.

Ma fundusz tej kanonii na dwóch summach: jednej 3000 złotych polskich na dobrach Krupie, w guberni wołyńskiej, w powiecie łuckim będącej, od której odbiera realnego dochodu złotych polskich 105 , od drugiej zaś summy 4000 złotych polskich na dobrach Zahorce, w tejże guberni, w powiecie krzemienieckim lokowanej, zalega prowent złotych polskich 140. Dla którego funduszu takiej szczupłości, utrzymuje obowiązki angelisty.

Nota. Z funduszu pojezuickiego miał także kanonik penitencjarz rocznego dochodu złotych polskich 400. Lecz, gdy ten fundusz jest zmniejszony, dochód także rzeczony nie jest już teraz wypłacany.

6. Kanonik funduszu Tomaszewskich. Wielmożny imć ks. Jan Junosza Piaskowski, pleban dywiński, w kraju zawsze mieszkający. Kanonia ta fundowana dla osób z familii Podhorodeńskich, Piaskowskich i Komornickich, a w niedostatku osób duchownych z tychże familii, dla innych z którąkolwiek rzeczoną familią złączonych.

Ma fundusz na summie 10 000, na dobrach Ławrowie, w guberni wołyńskiej, w powiecie dubieńskim leżących, od której złotych polskich 350 dochodu jeszcze dotąd nigdy nie miał sobie opłaconego, oraz na summie 5000 na dobrach Połonny w tejże guberni, w powiecie łuckim, od której realnego prowentu złotych polskich 175 odbiera.

7. Kanonik. Wielmożny imć ks. Walenty Znamirowski ${ }^{47}$, pleban w Kazimirce, zawsze w kraju mieszkający.

${ }^{45}$ Kanonia penitencjarza została utworzona około 1760 r. Funkcje penitencjarzy w kościele katedralnym spełniali od początku XVII w. jezuici, Królik, Organizacja diecezji łuckiej i brzeskiej, s. 203.

${ }^{46}$ Marcin Bossakowski STD et IUD, urodził się w 1758 r., do 1779 r. uczył się w szkołach publicznych w Winnicy, Humaniu i Szarogrodzie. Do obowiązków kapłańskich przygotowywał się od 1780 r. w seminarium łuckim. Od 1801 r. pełnił funkcje asesora w konsystorzu generalnym w Łucku, wiceoficjała, regensa seminarium łuckiego (do 1815 r.). W 1810 r. był już prałatem-archidiakonem. Miał sprawować także funkcję proboszcza lubomelskiego, Grabczak, Seminaria duchowne, s. 319-320. Zmarł 20 IX 1815 r. w Łucku w wieku 57 lat, zob. ADŁ, Księga zmarłych, s. 302 .

${ }^{47}$ Walenty Gładysz Znamierowski urodził się w 1759 r. w województwie podlaskim. Do kapłaństwa przygotowywał się w seminarium janowskim. Święcenia kapłańskie otrzymał w $1782 \mathrm{r}$. Początkowo był wykładowcą teologii moralnej w seminarium janowskim. W latach 1791-1806 pełnił funkcję regensa seminarium w Ołyce oraz nauczał historii Kościoła i ceremonii kościelnych. Był 

dziony.

Ma fundusz na dziesięcinach z Targowicy i Krasnego nadanych. Z dawna już zawie-

8. Kanonik funduszu Rokickiego ${ }^{48}$. Wielmożny imć ks. Józef Buchowiecki ${ }^{49}$, pleban w Tajgurach ${ }^{50}$, zawsze w kraju mieszkający.

Ma fundusz na summie 10000 na dobrach Powursk zwanych, w guberni wołyńskiej, a powiecie kowelskim leżących, od której dochodu odbiera corocznie złotych polskich 350.

9. Kanonik. Jaśnie wielmożny imć ks. Jakub Ignacy Dederko, obojga prawa doktor, proboszcz infułat kollegiaty ołyckiej, orderów Orła Białego i Świętego Stanisława kawaler, który tę kanonią katedralną, jako infułatom ołyckim ${ }^{51}$ na zawsze przyłączoną, posiada, zawsze w kraju mieszkający.

Nota. Kanonicy ci, dla szczupłości swych dochodów, plebanie i insze beneficja kościelne posiadają.

proboszczem w Kazimirce i dziekanem rówieńskim. Został uhonorowany godnościami: kanonika smoleńskiego, kanonika kapituły katedralnej w Łucku i prałata-scholastyka kapituły kolegiackiej w Ołyce, ADŁ, „Historia kościołów ołyckich”, k. 34-35; Grabczak, Seminaria duchowne, s. 341342.

${ }^{48}$ Kanonia funduszu Rokickiego pochodzi z okresu rządów diecezją łucką bpa Franciszka Kobielskiego (1740-1755), zob. Królik, Organizacja diecezji tuckiej i brzeskiej, s. 203. Została najprawdopodobniej ufundowana przez ks. Antoniego Jana Rokickiego h. Lubicz, proboszcza kowelskiego. On pierwszy został obdarzony tą godnością. Oprócz tego był kanonikiem kapituły kolegiackiej w Sandomierzu (kanonia prebendy Piekarska, 20 VIIII 1737-1753). Zmarł 28 VIII 1758 r. ADŁ, Księga zmarłych, s. 276; J. Szczepaniak, Duchowieństwo diecezji krakowskiej w XVIII wieku. Studium prozopograficzne, Kraków 2010, s. 146, 679; tenże, Spis prałatów i kanoników kapituty katedralnej oraz kapitut kolegiackich diecezji krakowskiej, s. 33.

${ }^{49}$ Józef Buchowiecki urodził się w 1751 r., święcenia kapłańskie otrzymał w 1777 r., dziekan ostrogski, prepozyt tajkurski (1785-1811), zmarł 8 XI 1811 r. w Tajkurach, zob. ADŁ, Księga zmarłych, s. 358.

${ }^{50}$ Tajkurach, dek. ostrogski.

${ }^{51} \mathrm{~W} 1800$ r. został sporządzony (na polecenie władz) dokument zatytułowany: „Kapituła i duchowieństwo przy kościele kolegiaty ołyckiej” (ADŁ, „Historia kościołów ołyckich”, k. 32-40). Wpisany tam został biogram bpa Jakuba Ignacego Dederki: „Pierwszy prałat, proboszcz, infułat ksiądz Jakub Dederko, biskup miński, kanonik katedralny wileński i łucki, orderów polskich kawaler, lat 49 mający, mieszka w kraju imperji. Do stanu duchownego w roku osiemnastym wieku swego powołany, w seminarium wileńskim edukował się, a w Akademii Wileńskiej laurem doktorii i obojga prawa i teologii zaszczycony. $Z$ kapituły wileńskiej był raz deputatem, a razy trzy prezesem na Trybunale Wileńskim compositi iudicii. Kapituły zaś łuckiej był podobnież deputatem na Trybunał Lubelski”, tamże, k. 32. W uzupełnieniu tego biogramu należy dodać: J.I. Dederko urodził się 25 VII 1751 (rok jego urodzenia u różnych autorów: 1750-1753) na Litwie. W latach 1770-1773 należał do zakonu jezuitów, biskup miński od 1798 r., w 1816 r. odsunięty od zarządu diecezją mieszkał w Ołyce, gdzie zmarł 13 II 1829 r. i tam został pochowany, L. Grzebień, Dederko Jakub Ignacy, w: Encyklopedia katolicka, t. 3, Lublin 1979, kol. 1083-1084; Tylus, Nowe źródła do biografii biskupów, s. 461. 


\section{Kanonicy bez żadnego dochodu}

Podług erekcyi swojej, z temiż kanoniami inne beneficia ecclesiastica posiadać mogący.

1. Wielmożny imć ks. Michał Szymkowicz Szkliński ${ }^{52}$.

2. Wielmożny imć ks. Łukasz Świebocki ${ }^{53}$, proboszcz krzemieniecki.

3. Wielmożny imć ks. Rafał Wojna Orański, proboszcz w Monasterzyskach.

4. Wielmożny imć ks. Michał, syn Krzysztofa, Maniecki ${ }^{54}$. Wyświęcony na kapłaństwo przez jaśnie wielmożnego śp. Wołłowicza, biskupa łuckiego w roku 1768, do którego kapłaństwa brał nauki w seminarium łuckim. Był wikarym w Porycku lat sześć, proboszczem wiszeneckim i dziekanem torczyńskim lat szesnaście. Stamtąd do katedry łuckiej przeniesiony i instytuowany na poddziekanią i plebanią łucką w roku 1791. W roku 1782 od jaśnie wielmożnego Turskiego, biskupa podtenczas łuckiego, kanonią honoralną łucką, w roku zaś 1783 od jaśnie wielmożnego Wodzińskiego, biskupa smoleńskiego kanonią katedralną smoleńską, w roku 1796 urzędem dziekana łuckiego zaszczycony. Kommissarza w Kommissyi Likwidacyjnej, od Rzeczypospolitej Polskiej ustanowionej, sprawował publiczny urząd. Potym kanonię katedralną łucką, bez dochodu będącą, otrzymał.

Kanonicy ci wszyscy w kraju znajdują się.

Nota. Ponieważ prałaci i kanonicy, wyż wyrażeni, mają niektórzy plebanie, przy których wiadomość o swych naukach i innych stopniach opisać są obowiązani, przeto takowa wiadomość o tych tylko daje się, którzy plebaniów w innym miejscu nie mają żadnych.

\section{Dochody wspólne kapituly}

Dochody takowe na utrzymanie fabryki kościoła i mieszkań, na światło i wino do kościoła, utrzymywanie apparatów kościelnych oraz na: kantorów, organistów, zakrystianów, dzwonników, jako też inne osoby do usług kościelnych potrzebne, tudzież, z reszty rzadko pozostającej, na płacenie czyli dystrybucyje codzienne dla prałatów i kanoników odbywających funkcyje katedralne, przepisem prawa o katedralnych kościołach i kapitułach ustanowione, jako też na prawne do windykacyi zaległych dochodów i inne potoczne lub nadzwyczajne wydarzające się ekspensa, aktualnie posiada kapituła:

1. W dobrach wsi Smohylów zwanej, w powiecie włodzimierskim, w guberni wołyńskiej będącej, mającej dusz 79, intraty zaś teraźniejszej złotych polskich 1500 .

2. Ze wsi Wyczółek, w guberni tejże, w powiecie dubieńskim leżącej (z której dochodów opatruje kapituła szpital św. Łazarza), mającej dusz 80, odbiera intraty złotych polskich 2000 .

3. Z części wsi Zieleniewa, w guberni tejże, a powiecie włodzimierskim będącej, mającej dusz 31, dochodu rocznego odbiera złotych polskich 300.

4. Od summ na dobrach różnych lokowanych odbiera procentu złotych polskich 2677 groszy 15.

5. Od summy na dwóch kamienicach w Łucku lokowanej złotych polskich 350.

6. Czynszu i prowentu z mieszkań rocznego złotych polskich 486 .

7. Od summ na 47 anniwersarzów, zapisanych i na dobrach lokowanych, dochodu (który się dzieli na całe duchowieństwo przy katedrze będące) realnie odbieranego złotych polskich 1592 groszy 15.

${ }^{52}$ Michał Szkliński proboszcz opaliński (1801-1810), zmarł 27 IV 1810 r. w Opalinie, zob. ADŁ, Księga zmarłych, s. 135.

${ }^{53}$ Łukasz Świebocki zmarł 10 II 1800 r. w Łucku, pochowany w kościele bernardyńskim, zob. ADŁ, Księga zmarłych, s. 47.

${ }^{54}$ Michał Maniecki, proboszcz w Skurczu (1804-1826), zmarł 7 I 1826 r. w Skurczu w wieku 86 lat, zob. ADŁ, Księga zmarłych, s. 8. 
8. Od summ na altaryje zapisanych, na dobrach lokowanych, roczny dochód realny złotych 752 groszy 15.

$\left[{ }^{\mathrm{d}}\right]$

Littera B.

$1^{\text {mo }}$ Od summ lokowanych w guberni wołyńskiej, w powiecie dubieńskim, na dobrach Chocimiu złotych 302 groszy 15, w powiecie ostrogskim na dobrach Tarantyjowie złotych 280. Także od summ na kahałach żydowskich będących: w Międzyrzecu złotych 350, w Kowlu złotych 140, w Horochowie złotych 35, od wielu lat zalega. Tudzież czynsz i prowent z gruntów i mieszkań złotych 723 groszy 15 nie wypłacany.

Littera C.

$2^{\text {do }}$ Prowent na anniwersarze od summ w guberni wołyńskiej, powiecie dubieńskim, na dobrach Koblinie złotych 35, na dobrach Ławrowie także złotych 35, na kahałach zaś żydowskich: w Międzyrzecu złotych 280, w Torczynie złotych 70, w Łucku złotych 260 groszy 22, w Stepaniu złotych 52 groszy 15, w Ołyce złotych 45 groszy 15, w Włodzimierzu złotych 35 corocznie należący, od wielu lat jest zawiedziony.

Nota. Z dóbr Dołhawola z przysiółkami zaprzysiężonego dochodu złotych polskich 5237 groszy 12 mających po odtrąceniu wyznaczonego na szpital i inne obowiązki dochodu, reszta należała do ogólnej massy kapitulnej. Lecz, gdy te dobra przez rząd najwyższy są winną possessyją oddane, już stamtąd kapituła żadnego nie odbiera dochodu.

\section{Obowiązki powszechne prałatów i kanoników \\ kapitułę składających}

Lubo nie wszyscy ciągle przy katedrze rezydują, ale tylko niektórzy, zawierają w sobie powinność w pewnych czasach zjeżdżania do katedry i bawienia przy niej, prócz tego odbywanie posług innych, tak krajowych, jak diecezjalnych, na funkcjach publicznych, do których byli i są wzywani. Dla dobrego jednak rządu i użyteczności publicznej, obowiązki w takowym są podziale:

1. Do zastępowania w funkcjach biskupiemu charakterowi własnych, za jaśnie wielmożnego imci księdza biskupa miejscowego, rządem diecezyi zatrudnionego i na pomoc prac jego jaśnie wielmożny imć ksiądz suffragan należy.

2. Do pilnowania chwały Boskiej, porządku kościelnego, opowiadania słowa Bożego i innych funkcyi kościelnych, jaśnie wielmożni imcie księża proboszcz koadiutor oraz kustosz i kantor są obowiązani.

\footnotetext{
${ }^{\mathrm{d}}$ Wykreślono w oryginale tekst: Littera A. Z funduszu pojezuickiego, podług kompozycyi z Kommissyją Edukacyjną, na dopełnienie tych obowiązków, które w katedrze i diecezyi przez księży jezuitów utrzymywane były, jako to: nauczania ludu artykułów wiary i moralności i odwiedzania kościołów po diecezyi, na utrzymanie kaznodziejów, spowiedników przy katedrze łuckiej, jako też teologii professorów seminarium, na plebana i wikariusza kościoła krzemienieckiego, także plebana i wikariusza kościoła mielnickiego [?] oraz na utrzymywanie potrzeb tych kościołów, niemniej na księdza prebendarza przy kościele ostrogskim i na inne tegoż kościoła potrzeby funduszem z dóbr pojezuickich oznaczone, dochód naznaczony wynosił złotych polskich 12 800, z których że odpadło na dobrach Okniny zwanych, w guberni podolskiej leżących, złotych 9000 , jako też z jurydyki w Krzemieńcu złotych 800. Reszty tego dochodu odbieranego realnie ma kapituła, tylko z dóbr Łyszcza, w guberni wołyńskiej, powiecie łuckim będących, złotych 3 000. Dochód tedy ogólny kapituły wraz z odbieranym na anniwersarze i altaryje, tudzież z reszty funduszu pojezuickiego, rocznie czyni złotych polskich 12658 groszy 15. Tenże dochód zawiedziony wynosi rocznie złotych polskich 12444 groszy 22.
} 
3. Wyższy rząd nad duchowieństwem niższym przy kościele katedralnym należy do jaśnie wielmożnego imci księdza dziekana.

4. Strzeżenia i trzymania w porządku archiwum oraz wszystkich dokumentów do praw kapituły i kościoła katedralnego należących, niemniej do przedstawiania wszystkich interessów jaśnie wielmożnego imci księdza biskupa miejscowego i kapituły, na wielmożnego imci księdza kanclerza włożony jest obowiązek.

5. Nad edukacyją publiczną wielmożni imcie księża scholastyk i kanonik Olszewski dozór sobie oddany mają.

6. Do rządu i dozoru szpitalów jaśnie wielmożni ichmoście księża dziekan, tudzież kanonicy: książę Jabłonowski i Glinka należą.

7. Pilnowanie dochodów należących do zgromadzenia wielmożnym ichmościom księżom archidiakonowi łuckiemu oraz kanonikom Dederkowi i Orańskiemu jest oddane.

Innych zaś osób kapituły, aby na miejsce wyszczególnionych wyżej, a z słusznej przyczyny do spełniania swego obowiązku przeszkodę mających, użyte, zastępnie włożony, ich obowiązek dopełniały, własną jest powinnością.

\section{Duchowieństwo niższe}

\section{Wikariusze}

1. Jmć ks. Michał Maniecki, wyż wyrażony katedralny kanonik, jest poddziekanim, który po dziekanie katedralnym ma zwierzchność nad duchowieństwem niższym przy tymże kościele, wraz i rząd parafii łuckiej z innemi sprawuje. Approbowany do słuchania spowiedzi w roku 1797, dnia 31 marca do lat dwóch od urzędu duchownego łuckiego, ma zaświadczenie egzaminu swego.

2. Ks. Ignacy Mikulski ${ }^{55}$.

3. Ks. Wawrzyniec Wierzbicki.

4. Ks. Marcin Gągalski ${ }^{56}$, podkustoszy.

5. Ks. Piotr Ketliński ${ }^{57}$.

6. Ks. Łukasz Zawadzki ${ }^{58}$.

7. Ks. Michał Hussakowski ${ }^{59}$.

${ }^{55}$ Ignacy Mikulski kanonik honorowy łucki, senior angelistów, zmarł 10 XI 1826 r. w Łucku w wieku 78 lat, zob. ADŁ, Księga zmarłych, s. 360.

${ }^{56}$ Marcin Gągalski, syn Mikołaja, urodził się w 1756 r. w rodzinie szlacheckiej, początkowo uczył się w szkołach w Złoczowie i Lwowie. Przygotowanie do kapłaństwa rozpoczął w seminarium łuckim w 1778 r., w 1781 r. otrzymał święcenia kapłańskie. W latach 1802-1837 był kanonikiem łuckim. W latach 1804-1821 nauczał śpiewu kościelnego w seminarium łuckim. Zmarł w 1838 r., Grabczak, Seminaria duchowne, s. 320-321.

${ }^{57}$ Piotr Ketliński kanonik honorowy łucki, mansjonarz św. Aniołów Stróżów w katedrze łuckiej, przez 18 lat był wikariuszem w Turzysku, 18 lat w parafii katedralnej w Łucku, zmarł 20 VI 1805 r. w wieku 68 lat w Bawołokach, par. Targowica, pochowany w Targowicy, zob. ADŁ, Księga zmarłych, s. 197.

${ }^{58}$ Lukasz Zawadzki kanonik honorowy łucki, zmarł 2 V 1829 r. w Łucku w wieku 73 lat, zob. ADŁ, Księga zmarłych, s. 141.

${ }^{59}$ Michał Hussakowski urodził się w 1764 r., święcenia kapłańskie otrzymał w 1790 r., wykładowca w seminarium łuckim od 1805 r. historii Kościoła, teologii dogmatycznej, Pisma św., kanonik i wikariusz łucki, zmarł 5 X 1811 r. w Łucku w wieku 47 lat, zob. ADŁ, Księga zmarłych, s. 319; Grabczak, Seminaria duchowne, s. 322. 
8. Ks. Paweł Bossakowski ${ }^{60}$.

Fundusz księża wikariuszowie posiadają w dobrach Sadów z przysiółkami: Horzwin, Żukowiec, Koszów i Wólka Sadowska zwanych, w guberni wołyńskiej, w powiecie włodzimierskim leżących, przez Jerzego Chwalczewskiego, biskupa łuckiego rzymsko-katolickiego kupionych i na ten fundusz w roku 1548 nadanych, w których dobrach Sadowie liczy się dusz 258, w Horzwinie dusz 65, w Żukowcu dusz 76, w Koszowie dusz 35. [ ${ }^{\circ}$ ] Dochodu z tych dóbr rocznego zaprzysiężonego wynosi złotych polskich 18432 groszy 10. Takowa $z$ dóbr intrata obraca się na pensyje księżom wikariuszom ośmiu złotych polskich 4390, księżom mansjonarzom czterem złotych polskich 1000, księdzu kustoszowi prałatowi katedralnemu złotych 300. Także za dziesięcinę kościołowi parafialnemu torczyńskiemu złotych polskich 120, corocznie wypłacane. Reszta na utrzymywanie stołu powszechnego dla tychże księży wikariuszów ośmiu, niemniej dla mansjonarzów czterech, angelistów pięciu, tudzież seminarystów kleryków sześciu i fioletów czterech, jako też professora tegoż seminarium, za pomaganie i utrzymywanie poddaństwa, utrzymywanie i dostarczanie potrzeb gospodarskich, zapłatę służącym, reparacyje w dobrach i mieszkaniach wikariuszowskich przy kościele i ekspensa prawne na obronę dóbr i inne nieuchronne potrzeby.

$2^{\text {do }}$ Mają także dochód z czynszu od kamienic dwóch w Łucku będących złotych polskich 16, pensyi z funduszu księdza Tyszki przez kapitułę katedralną sobie wypłacanego złotych 40, tudzież z procentów od summ na różnych lokowanych miejscach, złotych polskich 878 groszy 15. Którego pieniężnego dochodu, ponieważ, według ustanowienia jaśnie wielmożnych ichmościów księży biskupów, część czwarta jest oddzielona na prawne ekspensa do windykacyi tychże procentów, tudzież na ekspensa parafialne, jako to: chowanie zmarłych ubogich, jeżdżenie do chorych w rozległej parafii i dawanie jałmużny potrzebującym, przeto zostać się powinne dla dziewięciu księży wikariuszów z altarystą św. Józefa rachowanych do podziału złotych polskich 700 groszy 26. Lecz ten prowent mianowicie od summ na kahałach żydowskich lokowanych, jako to: od miasta Łucka złotych polskich 269 groszy 15, od kahału w mieście Ołyce złotych 175, z miasteczka Stepania złotych polskich 49 corocznie należący i zaległy, pod prawną jest windykacyją. Takowej windykacyi potrzebuje także dochód należący od summ lokowanych na dobrach w guberni wołyńskiej, powiecie włodzimierskim, wsi Bożowie rocznie złotych 105, na dobrach Iwanicze złotych 140, na dobrach Radoszynie złotych 70 wynoszący, tudzież na wsi Peremiłowka złotych 31 groszy 15, w powiecie dubieńskim zalegający.

$3^{\text {tio }} \mathrm{Z}$ kompozycyi z Kommissyją Edukacyjną, z dóbr pojezuickich należało także przez kapitułę katedralną księżom wikariuszom wypłacanie czynszu z młyna łuckiego złotych 40, ale gdy część większa dochodów z funduszu pojezuickiego nie jest kapitule wypłacana, już tego czynszu księża wikariuszowie nie odbierają. In summa dochodu realnego mają złotych polskich 18527 groszy 6, zalegającego zaś prowentu złotych polskich 880 .

Obowiązki księży wikariuszów są: ustawiczne przy kościele katedralnym mieszkanie, śpiewanie codzienne w chórze, odprawianie mszy św. i innych funkcyi kościelnych, a najszczególniej staranie o dusze przez prace parafialne, nauki, administracyją sakramentów, tak zdrowym, jako i chorym oraz innych usług duchownych parochów urzędowi przyzwoitych sprawowanie, które w obszernej parafii przy pomocy księży mansjonarzów i angelistów pilnie i pożytecznie dopełniają. Wikariusz dziewiąty do pomocy prac wspólnych,

${ }^{\mathrm{e}}$ Wykreślono w oryginale tekst: w Wólce Sadowskiej dusz szlachty 34. Także w Koszowie szlachty dusz 17.

${ }^{60}$ Paweł Bossakowski kanonik łucki i wykładowca w seminarium łuckim, zmarł 27 XII 1812 r. w Łucku w wieku 47 lat, zob. ADŁ, Księga zmarłych, s. 414. 
parafialnych oraz innych duchownych usług, jako też mszy świętej odprawiania obowiązany, ks. Wiktoryn Kossakowski ${ }^{61}$, altarysta tit. świętego Józefa, ma fundusz na summie 10000 złotych polskich przez księdza Józefa Bętkowskiego ${ }^{62}$ roku 1763, dnia 10 grudnia zapisanej i na dobrach Witkowie w guberni wołyńskiej, w powiecie nowogródwołyńskim lokowanej, od której należący prowent złotych polskich 350, potrzebuje windykacyi.

Wyż wyrażeni księża wikariuszowie mają attestata odprawionego egzaminu i do słuchania spowiedzi approbacyje.

\section{Angeliści}

1. Imć ks. Józef Kronberg ${ }^{63}$, emeryt eks-professor i viceregens przez lat kilkanaście.

2. Wielmożny imć ks. Tobiasz Glinka, wyż wyrażony kanonik katedralny łucki.

3. Wielmożny imć ks. Marcin Bossakowski, professor seminarii, kanonik penitencjarz katedralny, wyż wyrażony.

4. Imć ks. Stanisław Podobiński, professor seminarii i kaznodzieja katedralny.

5. Imć ks. Józef Młodzianowski ${ }^{64}$, kaznodzieja per turnum z innemi.

W myśl fundacyi, mają swego proboszcza, czyli przełożonego, jednego z kapituły, którym teraz jest jaśnie wielmożny imć ksiądz dziekan katedralny łucki, Podhorodeński, którego, oprócz innych kościelnych obligacyi, obowiązkiem jest mieć w swojej administracyi wioski Dereczyn i Zawidów zwane, na fundusz dla tychże księży angelistów i proboszcza ich od jaśnie oświeconego księcia Aleksandra Sanguszka w roku 1626, dnia 2 stycznia zapisane i naznaczone, w guberni wołyńskiej a powiecie teraz włodzimierskim leżące, w których mianowicie, wiosce Dereczynie jest poddanych dusz 77, wolnych dusz 3, w wiosce zaś Zawidowie dusz 171, wolnych dusz 5. Obiedwie te wioski intraty, podług zaprzysiężenia, złotych polskich 3700 groszy 13 przynoszą, z której to intraty na pensyją dla księży angelistów pięciu i na sług kościelnych wypłaca corocznie kwartałami złotych polskich 1980, jako też obowiązany jest utrzymywać mieszkanie dla tychże księży. Stół zaś ciż księża angeliści, na mocy funduszu, mają wspólny z księżmi wikariuszami. Oprócz tego mają $\mathrm{z}$ różnych zapisów summ lokowanych na różnych dobrach złotych polskich 14 320, od których należący roczny prowent złotych polskich pięćset, groszy piętnaście prawie cały od lat kilku przez trudne odebranie i jeszcze trudniejsze prawowanie się, zalega. Obowiązkiem księży angelistów jest, oprócz odprawowania codziennie mszy świętej śpiewanej o Świętych Aniołach i innych obligacyi do funduszu swego przywiązanych, pomagać księżom wikariuszom in cura animarum i prócz tego każdy, mający jeszcze siły zdrowe, osobnym urzędem na użytek kościoła i diecezyi jest zatrudniony. Księża angeliści wszyscy mają attestata egzaminu i approbacyje do słuchania spowiedzi.

${ }^{61}$ Wiktoryn Kossakowski, mansjonarz, zmarł 28 XII 1808 r. w Łucku w wieku 56 lat, zob. ADŁ, Księga zmarłych, s. 415.

${ }^{62}$ Józef Bętkowski (Bentkowski) kanonik kujawski, zmarł 15 III 1769 r. w Łucku w wieku 35 lat, pochowany w kościele dominikanów, zob. ADŁ, Księga zmarłych, s. 86.

${ }^{63}$ Józef Kronberg kanonik honorowy i angelista łucki, zmarł 9 III 1802 r. w Łucku w wieku 59 lat, pochowany u bernardynów, zob. ADŁ, Księga zmarłych, s. 79.

${ }^{64}$ Józef Salezy Młodzianowski prałat kustosz katedralny łucki, asesor konsystorza generalnego w Łucku, proboszcz kowelski, zmarł 29 VIII 1836 r. w Wólce Kowelskiej w wieku 64 lat, pochowany w Kowlu, zob. ADŁ, Księga zmarłych, s. 277. 


\section{Mansjonarze}

1. Ks. Teodor Doktorowicz ${ }^{65}$.

2. Ks. Feliks Dekański.

3. Ks. Tomasz Czołowski.

4. Ks. Maksym Rafalski, diakon.

Dochodu swego mają:

Najprzód złotych polskich 1000, które kapituła, podług praw sobie służących, z dóbr Sadowa księży wikariuszów onym ustąpiła, mają oraz stół z temiż księżmi wikariuszami wspólny.

$2^{\text {do }}$ Od summ na dobrach lokowanych odbierają złotych polskich 787 groszy 15 . Dochód roczny, realnie odbierany, wynosi złotych polskich 1787 groszy piętnaście. Od summ zaś na kahale Żydów miasta Dubna lokowanych, należącego prowentu rocznego złotych polskich 105. Zalega od lat sześciu i ten windykacyi potrzebuje.

Obowiązki księży mansjonarzów są: przy kościele zawsze mieszkać, wraz z innym duchowieństwem $\mathrm{w}$ niedziele i święta wszystkie nabożeństwa odprawiać oraz msze śpiewane codziennie, tudzież officium mniejsze o Najświętszej Pannie Maryi śpiewać i w pracach parafialnych księżom wikariuszom dopomagać. Mieszkanie mają w kollegium murowanym przy kościele katedralnym, którego reparacyje kapituła katedralna swym utrzymuje kosztem. Trzej wyżej wyrażeni księża mansjonarze mają attestata egzaminu i approbacyje do słuchania spowiedzi.

Oprócz szkół publicznych, będących w Łucku, jest przy kościele katedralnym

\section{Seminarium}

w którym

1. Ksiądz regens, wielmożny imć ks. Marcin Olszewski, kanonik katedralny łucki.

2. Professor teologii pierwszy i viceregens, imć ks. Marcin Bossakowski, kanonik katedralny łucki.

3. Professor retoryki, ks. Stanisław Podobiński.

4. Professor teologii drugi, ks. Paweł Bossakowski, który oraz jest kapellanem szkół publicznych.

5. Professor kantu, ks. Marcin Gągalski, wikariusz katedralny.

Professorowie teologii dzielą prócz tego między siebie tłumaczenie Pisma świętego, historyi i ceremonii kościelnych i innych nauk sposobiących do stanu duchownego.

\section{Klerycy}

1. Tomasz Juściński ${ }^{66}$, po zakończonych naukach, dla niedostatku lat do kapłaństwa potrzebnych, użyty tymczasem do domowej edukacyi przy dworze jaśnie wielmożnego

${ }^{65}$ Ks. Teodor Doktorowicz angelista, zmarł 13 X 1833 r. w Łucku w wieku 81 lat, zob. ADŁ, Księga zmarłych, s. 328.

${ }^{66}$ Tomasz Juściński syn Mateusza, urodził się w 1775 r. w rodzinie szlacheckiej. Uczęszczał do szkół we Włodzimierzu Wołyńskim i Lublinie. Przygotowanie do kapłaństwa rozpoczął w seminarium łuckim w 1795 r., święcenia kapłańskie otrzymał w 1800 r. Do 1804 r. był wikariuszem w katedrze łuckiej oraz wykładał w seminarium łuckim język łaciński (1800-1803), teologię moralną (1804). Następnie był proboszczem w Wiszenkach (1804-1808), Mielnicy (1808-1816). Po powrocie do Łucka pełnił funkcję wikariusza katedralnego i wykładowcy w seminarium: teologii moralnej (1816-1817), języka łacińskiego (1817-1819), wymowy (1817-1819). Był uhonorowany godnością kanonika katedralnego w Łucku, Grabczak, Seminaria duchowne, s. 322. 
Podhorodeńskiego ${ }^{67}$, szambelana i kawalera, w miasteczku Deraźnym, w powiecie rówieńskim mieszkającego.

2. Piotr Orański ${ }^{68}$.

3. Jan Przegaliński ${ }^{69}$.

4. Józef Żmijowski.

5. Samuel Janiewicz, pozwolony do czasu na professora w szkołach publicznych włodzimierskich.

6. Józef Kuczyński.

7. Antoni Godlewski ${ }^{70}$.

8. Klemens Jedlecki.

9. Grzegorz Sośnicki ${ }^{71}$.

10. Mateusz Wyrzykowski ${ }^{72}$.

11. Antoni Kamiński ${ }^{73}$, dozorca i nauczyciel fioletów.

12. Jan Wroczyński.

13. Albin Kogutowski.

14. Ignacy Szymański.

15. Piotr Ławrykowski.

16. Jan Modrzyński.

\section{Fioleci}

1. Wincenty Przegaliński.

2. Feliks Krzyżycki.

3. Tomasz Suchodolski.

4. Adam Marcinkowski.

Fioleci są to dzieci ubogie, szlacheckie, w fioletowe sukienki ubrane dla posługi w kościele, a przy tym biorą edukacyją początkową w języku łacińskim i innych umiejętnościach.

Fundusz na utrzymanie seminarium, to jest: stół dla wszystkich, opał, światło, praczkę, reparacyją mieszkań, cyrulika, aptekę, książki, pensyje dla regensa, professorów i służących, odzież i wszystkie potrzeby dla fioletów jest takowy:

1. Z Sadowa, dóbr księży wikariuszów, podług funduszu, stół dla jednego professora, sześciu kleryków i czterech fioletów.

${ }^{67}$ Józef Podhorodeński h. Korczak (ok. 1740-1830) właściciel miasteczka Deraźne, Stownik geograficzny Królestwa Polskiego i innych krajów stowiańskich, t. 1, Warszawa 1880, s. 958.

${ }^{68}$ Ks. Piotr Orański, proboszcz tuczyński (1811-1831), zmarł 31 III 1831 r. w Tuczynie w wieku 56 lat, zob. ADE, Księga zmarłych, s. 104.

${ }^{69}$ Jan Nepomucen Przegaliński, proboszcz w Przewałach (1805-1834), w Maciejowie (18351856), kanonik honorowy łucki i żytomierski, zmarł 2 III 1856 r. w Maciejowie w wieku 80 lat, zob. ADŁ, Księga zmarłych, s. 71.

${ }^{70}$ Ks. Antoni Godlewski, komendarz w Łokaczach, zmarł 19 VII 1814 r. w Łokaczach w wieku około 40 lat, zob. ADŁ, Księga zmarłych, s. 230.

${ }^{71}$ Ks. Grzegorz Sośnicki, kanonik ołycki, zmarł 22 III 1831 r. w Ołyce na cholerę w wieku 59 lat, zob. ADŁ, Księga zmarłych, s. 94.

${ }^{72}$ Ks. Mateusz Wyrzykowski, proboszcz kobliński, wicedziekan dubieński, zmarł 15 II 1820 r. w Koblinie w wieku 42 lat, zob. ADŁ, Księga zmarłych, s. 53.

${ }^{73}$ Ks. Antoni Kamiński, proboszcz wiśniowiecki, zmarł 12 IX 1826 r. w Łucku, w szpitalu bonifratrów w wieku około 60 lat, zob. ADŁ, Księga zmarłych, s. 293. 
2. Od summ na różnych dobrach lokowanych, wynoszących do złotych polskich 58790 - procentu rocznego złotych polskich 2665 .

3. Z altaryi różnych przy kościele katedralnym zafundowanych regensowi i professorom applikowanych, także od summ na różnych dobrach lokowanych, wynoszących 23600 - procentu rocznego złotych polskich 956.

4. Z kompozycyi z Kommissyją Edukacyjną, z dóbr pojezuickich w powiecie krzemienieckim leżących, wyznaczono było na professora teologii złotych polskich dziewięćset. Lecz, gdy za rządów jaśnie wielmożnego Tutolmina ${ }^{74}$, generał-gubernatora, część dochodu $\mathrm{z}$ funduszu pojezuickiego przestała być płacona, z pozostałego prowentu seminarium odbiera teraz tylko złotych polskich 700 .

5. Jest dom z placem w mieście Łucku sytuowany, z którego przedtym do kilkuset złotych polskich bywał dochód, a teraz [ ${ }^{\mathrm{f}}$ ] opłata $\mathrm{z}$ tego domu zaledwie na reparacyją i utrzymanie jego wystarczać może. A tak, prócz stołu na jedenaście osób wspólnego z księżmi wikariuszami, całego dochodu pieniężnego aktualnego na seminarium złotych polskich 4321 . Lubo i ten nie bez trudności bywa odbierany i po niektórych miejscach przez lat kilka zalega.

Nota. Z wioski Światyja zwanej, do kościoła parafialnego aleksandryjskiego przedtym należącej, naznaczony jest na seminarium dochód złotych polskich 500 .

Oprócz wyżej wyrażonego duchowieństwa, mieszka także przy katedralnym kościele ks. Ignacy Drozdowicz ${ }^{75}$, lat 69 wieku swego mający, niegdy w zakonie jezuickim quatuor votorum profess, w którym nauki do duchowieństwa potrzebne odbywał. Po zgaszonym zakonie $^{76}$, przez lat 24 jest spowiednikiem aż dotąd i ducha zakonnego rządcą panien zakonnych klasztoru łuckiego świętej Brygitty, przez urząd namiesniczy biskupi approbowany, jest oraz zaszczycony honoralną kanonią łucką, ma egzaminu swego attestatum. Dochodu odbierał przedtym emerytalnej, pojezuickiej pensyi rocznej złotych polskich tysiąc i teraz za pół roku odebrał złotych polskich 500 .

\section{Słudzy kościelni}

Za śpiewanie psałterza, tak we dnie po skończonym w kościele katedralnym nabożeństwie, jako i w nocy, od summy złotych polskich 18000 na dobrach Łokacze i Różynie, w guberni wołyńskiej, w powiecie włodzimierskim na ten fundusz lokowanej, z procentu rocznego złotych polskich 630 wynoszącego, z którego na mszy 24, podług tego funduszu, przez księży przy tymże kościele będących, odprawiane, złotych polskich 24 corocznie wypłaca się. Mają dochodu, dzielącego się na cztery osoby, wraz i na światło w nocy do śpiewania potrzebne, aktualnie złotych polskich 606.

${ }_{\mathrm{f}}^{\mathrm{f}}$ Wykreślono w oryginale: dla coraz większego upadku miasta.

${ }^{74}$ Timofiej Iwanowicz Tutolmin (1740-1809), od 1793 r. generał-gubernator miński, wołyński i bracławski. W drugim rozbiorze Polski Rosja zajęła ziemie na wschód od linii Druja-PińskZbrucz.

${ }^{75}$ Ignacy Drozdowicz, syn Stanisława i Anny, urodził się 31 I 1728 r. w Lesku. Do zakonu jezuitów wstąpił 6 VIII 1744 r. w Krakowie. Święcenia kapłańskie otrzymał w 1757 r. w Lublinie. Pracował jako misjonarz w Czeczelniku (1760-1761), wykładowca retoryki w Owruczu (1761-1762), Barze (1762-1763), Stanisławowie (1763-1765), wykładowca filozofii w Winnicy (1765-1767) i Kamieńcu Podolskim (1767-1769), wykładowca teologii moralnej w Łucku (1769-1773). Zmarł 15 VIII 1812 r. w Łucku, zob. ADŁ, Księga zmarłych, s. 261; Encyklopedia wiedzy o jezuitach, S. 132 .

${ }^{76}$ Papież Klemens XIV skasował zakon jezuitów w 1773 r. 
2. Za śpiewanie w tymże kościele, wraz z graniem na organach trzy razy na dzień codziennie hymnu o Najświętszej Pannie Maryi - „Omni die dic Mariae” - z funduszu od summy złotych polskich 30000 na dobrach Wyżgródku w guberni wołyńskiej, w powiecie krzemienieckim lokowanej, odbierają realnego dochodu rocznego złotych polskich 1050 .

\section{Parafia}

Składa się z miasta Łucka i wiosek naokoło przyległych № 46. Rozciąga się wzdłuż mil 3, wszerz mil 2. Zamyka w sobie dusz na Wielkanoc kommunikujących 2481. Parochami są onej, jako się wyżej opisało, księża wikariuszowie katedralni pod przewodnictwem księdza poddziekaniego swego, a przy pomocy księży mansjonarzów i angelistów. Liczba ochrzczonych w tym roku, od dnia 1 Ianuarii do ostatniego Novembris, męskiej płci 40, żeńskiej 51, in summa 91. Zmarłych męskiej płci 63, żeńskiej 54, in summa 117. Zaślubionych par 43.

Znajdują się także w tej parafii łuckiej księża, którzy z ruskiego uniackiego przyjęli obrządek łaciński:

1. Ks. Gabriel Sawicki ${ }^{77}$ jest kapellanem przy kościele łuckim świętego Jakuba, bonifratrów, mający obowiązek msze święte funduszowe odprawiać i usługi duchowne dla chorych, w szpitalu tymże bonifratelskim będących, czynić, który żadnej dotąd nie ma pensyi.

2. Ks. Atanazy Bielecki ${ }^{78} \mathrm{w}$ dobrach Iwanczyce, u jaśnie wielmożnego Bystrego ${ }^{79}$ jest kapellanem. Ma pensyją roczną złotych 200 i ordynaryją sobie dożywotnie od tegoż obywatela zapisaną.

3. Ks. Michał Łazarowicz we wsi Krupie, na kapellanii u jaśnie wielmożnej niegdy Ledóchowski, wojewodziny czerniechowski zostając, miał do jej życia wyznaczoną sobie pensyją, po której śmierci, teraz bez życia sposobu pozostał.

Takowy rapport przy przyciśnieniu pieczęci naszej kapitulnej i podpisie ręki sekretarza naszego kapitulnego, rękami własnemi podpisujemy.

Dan w Łucku, dnia 30 miesiąca grudnia roku 1797.

Ks. Józef Nepomucen Junosza Piaskowski, proboszcz koadiutor katedralny łucki, orderu Świętego Stanisława kawaler, kapituły katedralnej łuckiej prezes mpp.

Ks. Marcin Olszewski, kanonik katedralny, regens seminarium łuckiego mpp.

Ks. Michał Maniecki, kanonik katedralny i poddziekani łucki mpp.

Z tego projektu przepisany rapport jest posłany do Berdyczowa 22 Ianuarii [1798].

${ }^{77}$ Ks. Gabriel Sawicki zmarł 26 VII 1806 r. w Łucku w wieku około 70 lat, zob. ADŁ, Księga zmarłych, s. 238.

${ }^{78}$ Ks. Atanazy Bielecki zmarł 7 I 1802 r. w Iwańczycach, pochowany w Ozdeniżu, zob. ADŁ, Księga zmarłych, s. 8.

${ }^{79}$ Romualda Bystrego i jego żony Anny z Rakowskich. 
$* * * * *$

\section{Dokument $n r 2$}

\section{Wiadomość o znajdującym się duchowieństwie w kapitule kościoła katedralnego luckiego $^{80}[1800$ r. $]$}

1. Imiona, przezwiska i godności?

2. Wiele od urodzenia lat?

3. Z jakiej kondycyi?

4. Jak dawno wstąpił w stan duchowny?

5. Jak dawno zostaje w niniejszym stopniu?

6. Jakich języków uczył się?

7. Gdzie mianowicie znajduje się?

8. Jakie beneficjum i urzędy posiadają i posiadali?

\section{Księża prałaci katedralni}

Szuffragan

1. Ksiądz Jan Chryzostom Kaczkowski, obojga prawa doktor, biskup kariopolitański, archidiakon brzeski, orderu Świętego Stanisława kawaler

2. 57

3. Szlachcic

4. Od lat 34

5. Od lat 19

6. Łacińskiego, francuskiego, włoskiego

7. W Dubnie

8. Jest proboszczem kościoła parafialnego dubieńskiego i szuffraganem łuckim. Był officjałem brzeskim lat 18, kommissarzem cywilno-wojskowym lat 3, deputatem na Trybunał Koronny, wizytatorem generalnym delegowanym w różnych czasach kościołów i klasztorów w diecezyi łuckiej sobie powierzonych.

\section{Proboszcz}

1. Ksiądz Leo Konstantym Sosnowski, biskup aretuzjański

2. 78

3. Szlachcic

4. Od lat 48

5. Od lat 20

6. Łacińskiego, włoskiego

7. W Ratnym

8. Jest proboszczem kościoła katedralnego łuckiego, był deputatem na Trybunał Koronny.

\section{Koadiutor proboszcza}

${ }^{80}$ Rękopis jest sporządzony $\mathrm{w}$ formie tabeli. Tutaj zrezygnowano $\mathrm{z}$ ujęcia tabelarycznego. Informacje o poszczególnych prałatach i kanonikach, ujęte w punktach (od 1 do 8), są odpowiedziami na pytania postawione na początku tekstu publikowanego źródła. 
1. Ksiądz Józef Junosza Piaskowski, obojga prawa doktor, kanonik katedralny krakowski, dziekan kollegiaty ołyckiej, infułat klimontowski, orderu Świętego Stanisława kawaler

2. 57

3. Szlachcic

4. Od lat 39

5. Od lat 19

6. Łacińskiego

7. W Równym

8. [Jest] koadiutorem probostwa katedralnego łuckiego, dziekanem kollegiaty ołyckiej, kanonikiem katedralnym krakowskim i proboszczem kościoła parafialnego rówieńskiego. Bywał deputatem na Trybunał Koronny lubelski i piotrkowski, kommissarzem cywilno-wojskowym, prokuratorem kapituły łuckiej i wizytatorem generalnym delegowanym kościołów i klasztorów w diecezyi łuckiej.

\section{Dziekan}

1. Ksiądz Jan Kanty Bożydar Podhorodeński, obojga prawa doktor, officjał generalny konsystorza rzymsko-katolickiego łacińskiego łuckiego, orderu Świętego Stanisława kawaler

2. 59

3. Szlachcic

4. Od lat 34

5. Od lat 26

6. Łacińskiego, francuskiego, niemieckiego i włoskiego

7. W Łucku

8. [Jest] dziekanem katedralnym łuckim i proboszczem mansjonarskim tytułu Świętych Aniołów Stróżów. Bywał kustoszem i archidiakonem katedry łuckiej, proboszczem po różnych parafialnych kościołach lat 34, surrogatem konsystorza łuckiego, deputatem po kilka razy na trybunały główne, sędzią kommisarzem w sprawach cywilnych, kommissarzem cywilno-wojskowym, delegatem na sejmy walne narodowe, proffessorem publicznym w Akademii Zamojskiej i wizytatorem generalnym kościołów i klasztorów w diecezyi łuckiej.

\section{Archidiakon}

1. Ksiądz Józef Umiński, obojga prawa doktor

2. 61

3. Szlachcic

4. Od lat 44

5. Od lat 3

6. Łacińskiego

7. W Ostrogu

8. Jest archidiakonem katedralnym łuckim i proboszczem kościoła parafialnego ostrogskiego. Był kanonikiem katedralnym łuckim, deputatem na Trybunał Koronny łubelski, prezydentem na kapitule generalnej księży karmelitów trzewiczkowych dawnej obserwancyi w diecezyi łuckiej, prokuratorem generalnym kapituły łuckiej i wizytatorem generalnym delegowanym kościołów i klasztorów w diecezyi łuckiej będących. 


\section{Kustosz} kawaler

1. Ksiądz Andrzej Chołoniewski, obojga prawa doktor, orderu Świętego Stanisława

2. 57

3. Szlachcic

4. Od lat 34

5. Od lat 10

6. Łacińskiego, francuskiego, włoskiego

7. W dobrach swoich dziedzicznych

8. Był w Rzymie rektorem kościoła nacjonalnego lat 10, officjałem bracławskim lat 12 , deputatem na trybunał, komissarzem cywilno-wojskowym.

\section{Kanclerz}

1. Ksiądz Michał Skirniewski, auditor Curiae Episcopalis, assessor konsystorza generalnego łuckiego

2. 40

3. Szlachcic

4. Od lat 23

5. Od lat 3

6. Łacińskiego, francuskiego, rossyjskiego i włoskiego

7. W Łucku

8. [Jest] kanclerzem katedralnym łuckim i proboszczem kościoła parafialnego klewańskiego. Był kapelanem w wojskach rossyjskich dla katolików ${ }^{81}$, proffessorem w szkołach publicznych i wizytatorem generalnym delegowanym kościołów i klasztorów w diecezyi łuckiej będących.

\section{Kantor}

1. Ksiądz Mikołaj Grott Faliszewski, kanonik katedralny chełmski

2. 70

3. Szlachcic

4. Od lat 41

5. Od lat 12

6. Łacińskiego

7. W Ratnym

8. Jest kantorem katedralnym łuckim, kanonikiem katedralnym chełmskim i proboszczem kościoła parafialnego rateńskiego. Był kanonikiem katedralnym łuckim, deputatem na Trybunał Koronny lubelski, kommissarzem cywilno-wojskowym, kommisarzem do rozgraniczenia dóbr królewskich od szlacheckich.

\section{Scholastyk}

1. Ksiądz Ignacy Mioduszewski, obojga prawa doktor, assessor konsystorza generalnego rzymsko-katolickiego łuckiego i prokurator generalny kapituły łuckiej

2. 59

3. Szlachcic

4. Od lat 43

${ }^{81}$ W 1791 r. został odznaczony złotym krzyżem „,za sprawowanie opieki nad katolikami w wojsku”, a w 1792 r. przyznano mu 300 rubli srebrnych pensji dożywotniej, Grabczak, Seminaria duchowne, s. 340. 


\section{Od lat 3}

6. Łacińskiego, francuskiego

7. W Łucku

8. [Jest] scholastykiem katedralnym łuckim. Był penitencjariuszem w tejże katedrze. Był proboszczem kościoła parafialnego mielnickiego lat 25, kanonikiem kijowskim, kanonikiem katedralnym łuckim, deputatem na Trybunał Koronny, kommissarzem likwidacyjnym do ofiary 10 grosza $^{82}$, professorem publicznym, tak w duchownych, jako też i w świeckich szkołach i wizytatorem generalnym delegowanym kościołów i klasztorów w diecezyi łuckiej będących.
Księża kanonicy katedralni
[1.] Kanonik
1. Ksiądz Stanisław Stecki
2. 62
3. Szlachcic
4. Od lat 46
5. Od lat 20
6. Łacińskiego, francuskiego
7. W Kijowie
8. Jest proboszczem katedralnym żytomierskim, opisany przy tymże kościele.

\section{[2.] Kanonik}

1. Ksiądz Jan książę Jabłonowski

2. $46^{83}$

3. Szlachcic

4. Od lat 25

5. Od lat 19

6. Łacińskiego, francuskiego

7. W Kowlu

8. Jest proboszczem kościoła parafialnego kowelskiego. Był kommisarzem w kommissyjach cywilno-wojskowej i porządkowej ${ }^{84}$ lat kilka i wizytatorem generalnym delegowanym kościołów i klasztorów w diecezyi łuckiej będących.

\section{[3.] Kanonik}

1. Ksiądz Marcin Wętęka Olszewski, sędzia surrogat konsystorza generalnego łuckiego i seminarium diecezjalnego łuckiego regens

2. 64

3. Szlachcic

4. Od lat 42

5. Od lat 19

6. Łacińskiego

7. W Łucku

${ }^{82}$ Podatek uchwalony w 1789 r. na Sejmie Wielkim.

${ }^{83}$ Urodził się 6 XII 1754 r., S. Tylus, XVIII-wieczne duchowieństwo na kartach metryk parafii Kowel, ABMK, t. 73 (2000) s. 423.

${ }^{84} \mathrm{~W}$ latach 1790-1792 pełnił stanowisko komisarza cywilnego i wojskowego dla powiatu włodzimierskiego, Tylus, XVIII-wieczne duchowieństwo, s. 423. 
8. Jest proboszczem kościoła parafialnego skoreckiego. Był kanonikiem brzeskim, proboszczem derażeńskim, dziekanem stepańskim, deputatem na Trybunał Koronny lubelski, kommissarzem cywilno-wojskowym i wizytatorem generalnym delegowanym kościołów i klasztorów w diecezyi łuckiej będących.

\section{[4.] Kanonik}

1. Ksiądz Marcin Bossakowski, Świętej Teologii Doktor, assessor konsystorza generalnego łuckiego

2. 42

3. Szlachcic

4. Od lat 20

5. Od lat 3

6. Łacińskiego, francuskiego

7. W Łucku

8. Jest mansjonarzem tytułu Świętych Aniołów Stróżów, penitencjariuszem rzymskim $\mathrm{w}$ katedrze, ksiąg cenzorem i egzaminatorem diecezjalnym. Był wikariuszem katedralnym łuckim, professorem publicznym i vice regensem $w$ tymże seminarium i wizytatorem generalnym delegowanym kościołów i klasztorów w diecezyi łuckiej będących.

\section{[5.] Kanonik}

1. Ksiądz Walenty Znamierowski, scholastyk kollegiaty ołyckiej i seminarium w tejże kollegiacie będącego regens

2. [41]

3.

4. [17]

5 .

6.

7.

8. Przy opisaniu duchowieństwa kollegiaty ołyckiej dokładnie opisany ${ }^{85}$.

\section{[6.] Kanonik}

1. Ksiądz Jan Nepomucen Piaskowski, kanonik katedralny żmudzki

2. 30

3. Szlachcic

4. Od lat 12

5. Od lat 3

6. Łacińskiego, włoskiego

7. W Dewinie

8. Był professorem w seminarium. Jest proboszczem dywińskim.

\section{[7.] Kanonik}

1. Ksiądz Józef Buchowiecki

2. 49

${ }^{85}$ „Prałat szósty, scholastyk, ksiądz Walenty Znamierowski, kanonik katedralny łucki i smoleński, z województwa podlaskiego, lat 41 mający. W seminarium janowskim sposobił się na kapłaństwo i w tymże był teologii moralnej profesorem. Kapłanem jest od lat 17”, ADŁ, „Historia kościołów ołyckich”, k. 34. 
3. Szlachcic

4. Od lat 26

5. Od lat 3

6. Łacińskiego

7. W Tajgurach

8. Jest proboszczem kościoła parafialnego tajgurskiego i dziekanem powiatu ostrogskiego. Miał beneficjum przy kościele parafialnym dubieńskim.

\section{[8.] Kanonik}

1. Ksiądz Dominik Wykowski, assessor konsystorza generalnego łuckiego

2. 48

3. Szlachcic

4. Od lat 17

5. Od lat 2

6. Łacińskiego

7. W Łucku

8. Jest mansjonarzem tytułu Świętych Aniołów Stróżów. Był pierwej wikariuszem katedralnym łuckim, proboszczem kościoła parafialnego sieleckiego, dziekanem powiatu włodzimierskiego i kommissarzem porządkowym powiatu tegoż lat kilka.

\section{[9.] Kanonik}

1. Ksiądz Michał Szkliński

2. 65

3. Szlachcic

4. Od lat 17

5. Od lat 12

6. Łacińskiego

7. W Kowlu

8. Był i komissarzem do wyprowadzenia intraty 10 grosza i komissarzem cywilnowojskowym.

\section{[10.] Kanonik}
1. Ksiądz Rafał Orański
2. 54
3. Szlachcic
4. Od lat 18
5. Od lat 5
6. Łacińskiego
7. W Monasterzyskach
8. Proboszcz monastyrzecki. Był komissarzem cywilno-wojskowym.

\section{[11.] Kanonik}

1. Ksiądz Michał Maniecki

2. 59

3. Szlachcic

4.

5.

6.

7. 
8. Przy opisaniu duchowieństwa przy katedrze łuckiej in collegiis będącego ${ }^{86}$, dokładnie jest opisany.

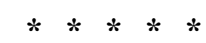

\section{Dokument nr 3}

Wiadomość o rocznych dochodach prelatur i kanonii katedralnych łuckich [po 1799 r.]

\begin{tabular}{|c|c|c|}
\hline Proboszcz $^{1}$ & $\begin{array}{l}\text { Cały fundusz ma [w] Litwie. Inwentarze dóbr tego } \\
\text { funduszu, znajdujące się in archivo capituli, nie } \\
\text { mają zebrania intraty rocznej. Okazują to inwentarze, } \\
\text { które się składa }\end{array}$ & 12000 \\
\hline Dziekan & $\begin{array}{l}\text { Cały fundusz mający w Litwie, podług } \\
\text { zaprzysiężonego w r. } 1789 \text { inwentarza, ma dochodu } \\
\text { złotych } 3875,22 \text { grosze. Późniejsze inwentarze } \\
\text { okazują, iż ma dochodu więcej nad złotych } 7000 \text {, } \\
\text { bo w r. } 1799\end{array}$ & $9301^{2}$ \\
\hline $\begin{array}{l}\text { Archidiakon } \\
\text { łucki }\end{array}$ & $\begin{array}{l}\text { Częścią z pierwiastkowego funduszu i nadania, } \\
\text { częścią z późniejszych zamian i inkorporacyi } \\
\text { funduszu kościoła św. Jakuba }{ }^{3} \text {, ma intraty rocznej } \\
\text { z karczmy pod klasztorem księży bernardynów } \\
\text { będącej, złotych } \\
\text { z jurydyki w mieście Łucku, złotych } \\
\text { za dziesięcinę z Korszowa, złotych } \\
\text { za dziesięcinę z Ratnowa, złotych } \\
\text { za dziesięcinę z Krasnego, złotych } \\
\text { za dziesięcinę z Połonny, złotych } \\
\text { z wioski Niemieckie zwanej, intraty rocznej } \\
\text { złotych } \\
\text { wytrąca się na szpital }{ }^{4} \\
\text { zostaje }\end{array}$ & $\begin{array}{c}300 \\
200 \\
200 \\
200 \\
40 \\
200 \\
500 \\
1640 \\
28 \\
1612\end{array}$ \\
\hline Kustosz & $\begin{array}{l}\text { Po odmianie pierwiastkowego funduszu na wsi } \\
\text { Łyszcze zwanej, a kustoszowi na fundusz nadanej } \\
\text { w r. } 1545 \text {. Teraz z Sadowa, dóbr księży wikariuszów, } \\
\text { ma rocznego dochodu }\end{array}$ & 300 \\
\hline $\begin{array}{l}\text { Archidiakon } \\
\text { brzeski }\end{array}$ & $\begin{array}{l}\text { Nie ma żadnego teraz dochodu, gdy cały fundusz } \\
\text { jego znajduje się w kordonie austriackim }\end{array}$ & \\
\hline Kanclerz & $\begin{array}{l}\text { Po rozmaitych odmianach swego funduszu miał } \\
\text { ostatecznie z Torczyna oznaczone sobie corocznie } \\
\text { złotych 200, lecz tych od czasu zabrania dóbr } \\
\text { biskupich nie odbiera }\end{array}$ & \\
\hline
\end{tabular}

${ }^{86}$ Tego dokumentu nie odnaleziono. 


\begin{tabular}{|c|c|c|}
\hline Kantor & $\begin{array}{l}\text { W r. } 1680 \text { fundowany na procencie od summy } \\
\text { złotych } 3500 \text { na Kniehinie }{ }^{5} \text { pod Targowicą. Lecz, } \\
\text { gdy żadnego w archivum capituli nie ma śladu tej } \\
\text { summy, przeto od dawna kantor jest bez wszelkiego } \\
\text { dochodu }\end{array}$ & \\
\hline Scholastyk & 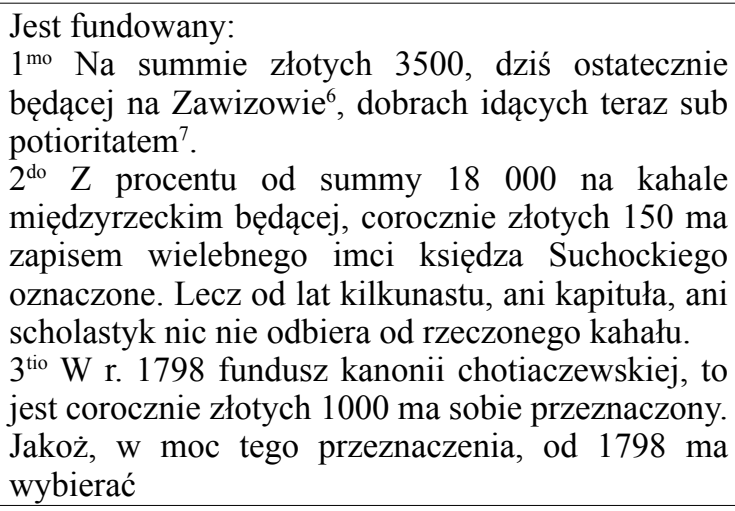 & 1000 \\
\hline $\begin{array}{l}\text { Kanonik } \\
\text { na Bokowy } \\
\text { fundowany }\end{array}$ & $\begin{array}{l}\text { Podług zaprzysiężonego w r. } 1789 \text { inwentarza, ma } \\
\text { dochodu rocznego }\end{array}$ & 1000 \\
\hline $\begin{array}{l}\text { Kanonik } \\
\text { penitencjarz }\end{array}$ & $\begin{array}{l}\text { Fundowany: } \\
1^{\text {mo }} \mathrm{Na} \text { summie złotych } 4000 \text { na Zahorcach, od } \\
\text { której z dawna nie odbiera procentu. } \\
2^{\text {do }} \text { Na summie złotych polskich } 3000 \text { na Krupie, od } \\
\text { której ma corocznie } \\
\text { Przez ordynacyją dochodów pojezuickich ma prawo } \\
\text { odbierać corocznie z kassy }\end{array}$ & $\begin{array}{l}105 \\
400\end{array}$ \\
\hline $\begin{array}{l}\text { Kanonik } \\
\text { na Torczynie } \\
\text { fundowany }\end{array}$ & $\begin{array}{l}\text { Z wyłączonych dla siebie gruntów i jurydyki, } \\
\text { nadanej niegdyś plebanom torczyńskim, ma, podług } \\
\text { zaprzysiężonego inwentarza w r. 1789, intraty }\end{array}$ & 285 \\
\hline $\begin{array}{l}\text { Kanonik } \\
\text { Rokickich } \\
\text { funduszu }\end{array}$ & $\begin{array}{l}\text { Od summy złotych } 10000 \text { na Powursku zapisanej, } \\
\text { mieć powinien dochodu rocznego } \\
\text { Lecz ten dochód od lat kilku nie dochodzi }\end{array}$ & 350 \\
\hline $\begin{array}{l}\text { Kanonik } \\
\text { Tomaszewskich } \\
\text { funduszu }\end{array}$ & $\begin{array}{l}\text { Od summy po części na Ławrowie, a po części na } \\
\text { Połonny zapisanej złotych } 10000 \text {, odbiera z kassy } \\
\text { kapitulnej rocznego dochodu, } \\
\text { a zaś o fundusz na Ławrowie zawiedziony toczy się } \\
\text { teraz proces }\end{array}$ & 350 \\
\hline $\begin{array}{l}\text { Kanonik } \\
\text { na Targowicy } \\
\text { fundowany }\end{array}$ & Nie ma żadnego dochodu & \\
\hline
\end{tabular}

${ }^{1}$ Prepozyt - pierwsza prałatura w łuckiej kapitule katedralnej.

${ }^{2}$ Tę kwotę wykreślono i zastąpiono ją kwotą: 5000.

${ }^{3}$ W latach 80. XVIII w. parafia św. Jakuba w Łucka została połączona z parafią katedralną.

${ }^{4}$ Szpital Świętego Ducha w Łucku.

${ }^{5}$ Kniahynin. 
${ }^{6}$ Zawizów - wieś nad Horyniem, w powiecie ostrogskim, Słownik geograficzny Królestwa Polskiego i innych krajów stowiańskich, t. 14, Warszawa 1895, s. 497.

${ }^{7}$ Sub potioritatem [lac.] - w zastawie.

\title{
THE CATHEDRAL CHAPTER IN LUTSK IN THE DOCUMENTS OF THE LATE EIGHTEENTH AND EARLY NINETEENTH CENTURY.
}

\begin{abstract}
Summary
The documents currently published come from fragmentary archive of the cathedral chapter of Lutsk, which is part of the Diocese Archive of Lutsk (the deposit in the Centre for Museums Libraries and Church Archives - ABMK in Polish). They show the cathedral chapter in Lutsk in the late eighteenth and early nineteenth century - personnel (including biographical data of some people), the obligations of its members, salary of both prelates and canons, as well as the common property of the chapter. The first and most detailed document (from 1797) also includes other cathedral clergymen connected with the cathedral (and the cathedral parish), that is the members of the collegiates: vicars, „mansjonarze”, ,angeliści” (the priests of lower rank in the church hierarchy), and the names of lecturers and students of the cathedral seminary. The documents were produced during the territorial reorganization of the Catholic Church in Russia, made in 1798 by the nuncio L. Litt on behalf of Pope Pius VI. The Diocese of Lutsk (with the cathedral chapter in Lutsk) was connected by personal union (Aequana principaliter) with the Diocese of Zhytomyr, whose cathedral chapter was in Zhytomyr.
\end{abstract}

Translated by Aneta Kiper 